\title{
STATISTICAL ANALYSIS OF DETAILED 3-D CFD LES SIMULATIONS WITH REGARD TO CCV MODELING
}

\section{OLDR̆ICH VÍTEK, JAN MACEK}

Czech Technical University in Prague, Department of Automotive, Combustion Engine and Railway Engineering, Technická 4, CZ-16607 Prague 6, Czech Republic, Tel.: +420224352507, Fax: +420224352500, E-mail: oldrich.vitek@fs.cvut.cz

\section{ZORAN PAVLOVIC, REINHARD TATSCHL}

AVL LIST GmbH, Advanced Simulation Technologies, Graz, Austria, E-mail: reinhard.tatsch|@avl.com

\section{ABSTRACT}

The paper deals with statistical analysis of large amount of detailed 3-D CFD data in terms of cycle-to-cycle variations (CCVs). These data were obtained by means of LES calculations of many consecutive cycles. Due to non-linear nature of Navier-Stokes equation set, there is a relatively significant CCV. Hence, every cycle is slightly different - this leads to requirement to perform statistical analysis based on ensemble averaging procedure which enables better understanding of CCV in ICE including its quantification. The data obtained from the averaging procedure provides results on different space resolution levels. The procedure is applied locally, i.e., in every cell of the mesh. Hence there is detailed CCV information on local level - such information can be compared with RANS simulations. Next, volume/mass averaging provides information at specific locations - e.g., gap between electrodes of a spark plug. Finally, volume/mass averaging of the whole combustion chamber leads to global information which can be compared with experimental data or results of system simulation tools (which are based on 0-D/1-D approach).

KEYWORDS: ENSEMBLE AVERAGING, LES, RANS, CYCLE-TO-CYCLE VARIATIONS, STATISTICAL ANALYSIS

\section{SHRNUTí}

Článek se zabývá statistickou analýzou velkého množství detailních 3-D CFD dat z hlediska mezicyklové variability. Tato data jsou získána pomocí LES simulací velkého počtu po sobě následujících cyklů. Díky nelinearitě Navier-Stokesových rovnic existuje relativně velká mezicyklová variabilita. A tedy každý cyklus je jiný - to vede k potřebě aplikovat statistickou analýzu založenou na průměrování z hlediska realizací, což umožňuje lepší pochopení mezicyklové variability ve spalovacích motorech včetně její kvantifikace. Data získána z průměrování poskytují výsledky na různých úrovních z hlediska prostorového rozlišení. Samotná procedura je aplikována lokálně v každé buňce výpočetní sítě - taková informace může být porovnána s výsledky RANS simulací. Dále je možné použít objemové/hmotnostní průměrování - např. v mezeře mezi elektrodami zapalovací svičky. Konečně Ize použít objemové/hmotnostní průměrování celé spalovací komory, což vede k získání globální informace, která může být porovnána s výsledky měření nebo výsledky simulací na systémové úrovni (které jsou založeny na 0-D/1-D př́stupu). KLIĆCOÁ SLOVA: PRŮMËrOVÁNÍ Z HLEDISKA REALIZACÍ, LES, RANS, MEZICYKLOVÁ VARIABILITA, STATISTICKÁ ANALÝZA

\section{INTRODUCTION}

Detailed 3-CFD calculations of ICE working cycle became more popular in last 2 decades due to significant increase of computer power (mainly caused by effective parallelization of available CFD SW tools). Moreover, LES (c.f. [1, 2]) approach offers significant improvement in terms of turbulence modelling and cycle-to-cycle variations (CCVs) - c.f. $[3,4,5]$. However, such calculations provide huge amount of data (in order of TB) which contain a lot of information. It is obvious that effective method to process the data is needed as it is not possible to go through all available information.

Statistical approach offers a lot of potential to achieve that due to the fact that both turbulence and CCV seem to behave like a stochastic property (to be more precise, it is not completely random as basic conservation laws have to be satisfied). Hence, the main target of the paper was to perform analysis of the data from statistical point of view. Moreover, 
the main emphasis was put on information regarding CCV including statistical convergence of averaged results. The analysis was supposed to be applied locally while local/ global values based on volume/mass averaging were derived to get CCV information at different levels of space resolution. Additional target was to create automatic post-processing scripts which could perform the analysis automatically for given data set. The averaging procedure and statistical analysis was applied to 2 different engine models (c.f. Table 1 and Figure 1 and 2) of a single-cylinder engine corresponding to small tumble-dominated SI ICEs.

\section{THEORETICAL BACKGROUND}

The mathematical model is based on standard CFD approach applied in commercial codes - in this case, the FIRE code [14] is selected as main simulation tool. More details about applied mathematical model can be found below in section 3 (Mathematical Model). However, LES calculation produce large amount of data - there are at least 2 reasons for that. First, fine mesh/time resolution is needed to resolve large turbulence eddies which carry most of the turbulence kinetic energy. Second, many consecutive cycles need to be calculated - this is caused by the nature of the LES approach as every calculated engine cycle is different. Based on that, statistical analysis of the data is needed to get the important knowledge from the huge amount of data.

The statistical evaluation of LES results is based on ensemble averaging which is generally defined in Equation 1 (more details can be found in $[6,7]), f_{n}$ corresponds to the $n$-th realization of the same experiment ( $\mathrm{n}$ is index only).

$F_{\text {avg }}\left(x_{i}, t\right)=\lim _{n \rightarrow \infty} \frac{1}{N} \sum_{n=1}^{N} f_{n}\left(x_{i}, t\right)$

In the case of internal combustion engine, each 'experiment realization' (total number of experiments is given by $N$ ) is represented by means of one engine cycle. As the ICE works periodically, it makes sense to define the averaging procedure by Equation 2 - the time variable $t$ is replaced by angle variable $\alpha$ (due to periodicity it makes sense to define $\alpha$ from range $\langle 0 ; 4 \pi>$ and use the angle definition of $\alpha+(n-1)$ $4 \pi$ for the $n$-th engine cycle), the cycle period is represented by the angle of $4 \pi$ (4-stroke engine -2 revolutions represent 1 engine cycle). All engine cycles are calculated consecutively - the results of previous cycle directly influence those of the
TABLE 1: Main engine parameters - version $A$ and version $B$ TABULKA 1: Hlavní parametry motoru - verze $A$ a verze $B$

\begin{tabular}{lccc|}
\hline Engine Parameter & Unit & Engine A: Value & Engine B: Value \\
\hline Bore-to-Stroke Ratio & {$[1]$} & 1.00 & 1.07 \\
\hline Compression Ratio & {$[1]$} & 11.5 & 10 \\
\hline Charging & & $\begin{array}{c}\text { Naturally } \\
\text { Aspirated }\end{array}$ & $\begin{array}{c}\text { Naturally } \\
\text { Aspirated }\end{array}$ \\
\hline Fuel & Gasoline (ON 95) & Gasoline (ON 95) \\
\hline Fuel Injection & DI & PFI \\
\hline Number of Intake Valves & 2 (phasing) & 2 \\
\hline Number of Exhaust Valves & 2 (phasing) & 2
\end{tabular}

following cycle. The above mentioned averaging approach is usually applied to velocity vectors, hence $f=u i$. Ensemble averaged turbulence kinetic energy corresponds to RMS values of all velocity vector components: $k=\frac{1}{2} u_{i, R M S} u_{i, R M S}$. RMS is defined in Equation 3.

However, the ensemble averaging (it is described in [6] as the most general type of Reynolds averaging) may cause a problem when applied to a case of ICE. The main reason is the fact, that in the case of multi-cylinder engine there is a 'low frequency' interaction (the process is slower when compared with engine basic frequency which corresponds to engine speed) among all those cylinders. This causes slow fluctuations of all flow properties. If averaging (Equations 2 and 3 ) is applied, these slow fluctuations directly influence the RMS value and hence, it is considered to be turbulence. However, it should be stressed that it is difficult to filter out these slow fluctuations to get rid of this problem. Hence, the kinetic energy based on relation $k=\frac{1}{2} u_{i, R M S} u_{i, R M S}$ is called resolved fluctuation kinetic energy (RFKE) to emphasize that it may contain kinetic energy related to cycle-to-cycle variations (CCVs). On the other hand, if CCV effect is not too strong, RFKE is dominated by turbulence kinetic energy - c.f. [7]. In a case of low CCV effects, it can be shown that CCV of mean velocity can be neglected which leads to the above-mentioned fact that RFKE is actually turbulence kinetic energy (details can be found in [7], section 8.2, especially Figure $8-5$ ). Moreover, results shown in this paper are based on single-cylinder engine calculations only (and the initialization procedure of both intake and exhaust ports is always the same) - therefore, the problem
$F_{\text {avg }}\left(x_{i}, \alpha\right)=\frac{1}{N} \sum_{n=1}^{N} f_{n}\left(x_{i}, \alpha+(n-1) 4 \pi\right)$

$$
F_{R M S}\left(x_{i}, \alpha\right)=\sqrt{\frac{1}{N} \sum_{n=1}^{N}\left[f_{n}\left(x_{i}, \alpha+(n-1) 4 \pi\right)-F_{a v g}\left(x_{i}, \alpha\right)\right]^{2}}
$$


of possible negative CCV effects on data analysis based on averaging is not present in this case.

To describe non-homogeneity of space distribution of a function $f_{n^{\prime}}$ uniformity index is defined in Equation 4. Concerning its value, the higher the better in terms of homogeneity - if the value is 1.0 , there is perfect distribution of the function $f_{n}$ in the considered domain ( $f_{n}$ is constant everywhere). Empirical experience is that if the value is more than 0.99 , the homogeneity is very good.

$$
\begin{aligned}
U I_{f}(t) & =\frac{1}{\iiint \rho d V} \iiint\left[1-\frac{1}{2}\left(\frac{f_{n}\left(x_{i}, t\right)}{F_{a v g, V}(t)}-1\right)\right] \rho d V \\
F_{a v g, V}(t) & =\frac{1}{\iiint \rho d V} \iiint f_{n}\left(x_{i}, t\right) \rho d V
\end{aligned}
$$

\section{MATHEMATICAL MODEL}

The mathematical model itself is based on unsteady 3-D compressible equation set (integral formulation) which is filtered either in space domain (and closed by LES turbulence

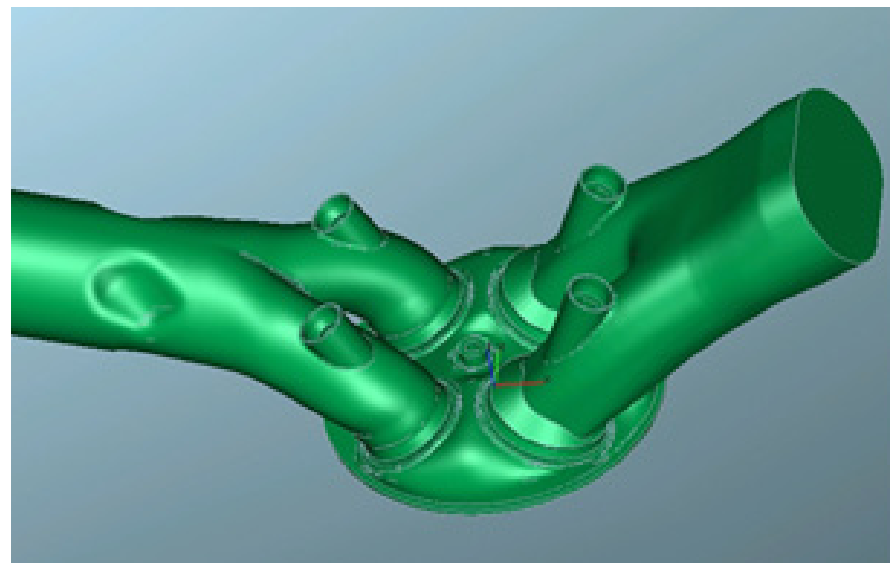

FIGURE 1: Basic engine layout - version $A$

OBRÁZEK 1: Základní konfigurace motoru - verze A

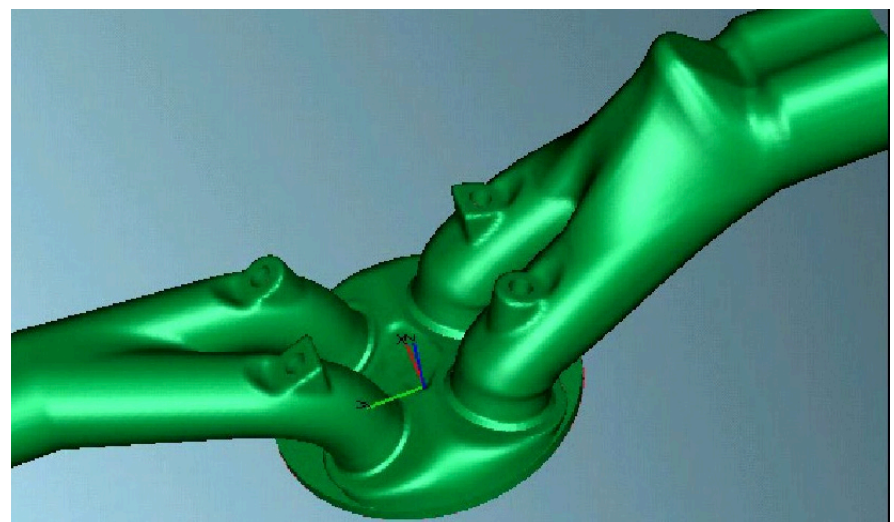

FIGURE 2: Basic engine layout - version B

OBRÁZEK 2: Základní konfigurace motoru - verze B model) or in time domain (and closed by RANS turbulence model). Details can be found in FIRE manuals [14] and in papers $[3,4]$. Regarding the engine model, there are 2 similar single-cylinder engine models of small SI ICE which were studied in terms of CCV - main engine parameters are summarized in Table 1 and basic engine layout is shown in Figure 1 and 2. Relatively complex modelling approach was adopted as engine version $A$ is direct fuel injection engine, hence low pressure liquid fuel injection had to be modelled, fuel evaporation and mixing had to be taken into account and turbulent flame propagation was applied - detailed model description can be found in $[3,4]$.

As the main focus of the work is CCV including its statistical analysis, LES approach $[1,2]$ to turbulence modeling was applied. Hence, many consecutive cycles were calculated under different engine operating conditions - c.f. section 4 (Computed Cases) for more details. LES approach requires fine mesh resolution to properly resolve large-scale turbulence structures. Based on initial testing and experience from SW provider, the typical mesh size of approximately $1.0 \mathrm{~mm}$ was selected - c.f. Table 2. However, certain RANS calculations were also performed using the same mesh (as for the LES case) to enable comparison of average results.

TABLE 2: Main mesh parameters for both engine version ( $A$ and $B$ ) TABULKA 2: Hlavní parametry sítě pro obě verze motoru ( $A$ a $B$ )

\begin{tabular}{|lccc|}
\hline Parameter & Unit & Engine A & Engine B \\
\hline Typical Mesh Size & {$[\mathrm{mm}]$} & $<1.0$ & $<1.0$ \\
\hline Min. Amount of Mesh Cells & {$[1]$} & $1.7 \mathrm{M}$ & $1.1 \mathrm{M}$ \\
\hline Max. Amount of Mesh Cells & {$[1]$} & $3.3 \mathrm{M}$ & $2.8 \mathrm{M}$ \\
\hline Total Amount of Meshes & {$[1]$} & 237 & 77 \\
\hline Max. Angle Interval of Single Mesh Set & {$[\operatorname{degCA}]$} & 5 & 10
\end{tabular}

\section{COMPUTED CASES}

Regarding the cases when statistical analysis (described in section 2) was needed, the following can be stated. The method was initially proposed during EU FP7 project LESSCCV and it was further refined recently. There is huge amount of data (in order of TB) which was 'created' during LES calculations in last 5 years. These data mainly concern engine models from Table 1. The following calculations were performed. Motored regime of both engines (c.f. Table 1) at different engine speeds. Combustion regime of engine version $A$ at different engine speeds under low engine load. Moreover, different calculation configurations were tested - classical approach while removing ports from calculation domain when corresponding valves were closed, coupled/ 
decoupled domain case when both intake/exhaust ports were part of the calculation domain all the time (i.e., no port removal), two-way coupled 1-D/3-D simulation when boundary conditions (for 3-D CFD calculation) were provided by 1-D model (running in parallel) of the whole engine setup. Details concerning these simulations can be found in $[3,4]$.

Due to the fact that huge amount of data was processed, only selected results are presented in this paper. The main goal is to demonstrate typical features of the analysis based on statistical approach with regard to CCV. Regarding the presented data, different results are presented. First, statistical analysis was performed at each computation cell of the mesh at selected crank angle positions (typically each $45 \operatorname{deg}(A)$. Hence, local information is available in the whole computational domain. Second, local data at special location(s) ware considered - this mainly concerns engine spark plug (to be more precise, the gap between spark plug electrodes is considered). This information is actually based on the data from certain space volume, which consists of few neighboring computation cells. Third, global data ware evaluated - such values are supposed to provide information regarding the whole computational domain (typically the whole combustion chamber) - example of such information can be average in-cylinder temperature, average in-cylinder kinetic energy or combustion progress with respect to crank angle. This information is usually important when comparison with experimental data is performed.

\section{DISCUSSION OF RESULTS}

Example of results of averaging procedure application is shown in Figure 3, 4,5 and 6. The data corresponds to 2 cuts of combustion chamber while showing average velocity vector magnitude and RFKE. It was computationally demanding task to process 45 consecutive cycles in terms of all 3-D CFD data - this was done at every $45 \operatorname{degCA}$ of engine cycle (16 times per engine cycle). The result of averaging procedure is plotted for different amount of cycles, which were considered during statistical analysis. This is important to find out the minimum amount of cycles needed to obtain statistically converged results (in other words: how many cycles are required so that the averaged values do not change when adding additional cycles into statistical analysis procedure). In this particular case, it seems that 10-15 cycles are needed to obtain converged value of $1^{\text {st }}$ order statistical moment (average velocity vector) while at least 40 cycles are required to get converged value of $2^{\text {nd }}$ order statistical moment (RFKE). However, reasonable values of both statistical moments ( $1^{\text {st }}$ order and $2^{\text {nd }}$ order) are achieved after 10 cycles. There is an interesting fact, that both velocity vector magnitude field and RFKE one seem almost the same when averaging is applied after 15 and 20 cycles. However, once the averaging is applied after more cycles, there are visible changes in averaged values (this mainly applies to higher order statistical moments, e.g. RFKE). The results were checked once again to be sure that no procedural error was made. There seems to be a misleading convergence of statistical properties when 15-20 cycles are calculated. Hence, the final recommendation is to calculate at least 10 consecutive cycles to get reasonably good data in terms of CCV. On the other hand, if more precise information is needed, at least 40 cycles are required and it is strongly recommended to check statistical convergence in terms of the amount of cycles. This conclusion is supported by results of other researchers from EU FP7 project LESSCCV (c.f. [5]) when dealing with similar issues while considering different engine types.

Comparison of averaged LES results with RANS models, which can predict only averaged values and turbulence kinetic energy, is shown in Figure 7 and 8. The LES simulation set-up respects recommended values (concerning mainly the mesh size, the time step and sufficient number of consecutive cycles) so that it is reasonable to believe that LES should have the best ability to predict. This statement is supported by the well-known fact that RANS 2-equation turbulence models are not too accurate when applied in internal combustion engines. The applied RANS models differ significantly, the AVL (the developer of FIRE code) recommends the k- $\zeta-f$ model (c.f. $[8,9,10])$ for engine application. The standard $k-\varepsilon$ model (c.f. $[11,12]$ ) was selected to test the performance of the old well-known RANS model. As it is clear from the figures, the averaged velocity vector magnitude field is relatively similar for all applied turbulence models. On the other hand, there are significant differences in predicted turbulence kinetic energy. The authors are aware of the fact that the RANS approach is based on time averaging while the averaged LES is based on ensemble averaging. These two approaches are not the same, especially for the case of ICE (periodic solution). On the other hand, it is usually expected that the difference between those is relatively small. This statement is supported by the results of averaged velocity vector magnitude (left column in Figure 7 and 8). Based on that, the difference in predicted turbulence kinetic energy seems to be too large. Even from qualitative point of view, the results are quite different. Generally speaking, the averaged LES approach predicts significantly higher levels of turbulence kinetic energy - this statement holds especially for the regions with expected high levels of turbulence. When comparing both RANS models, they seem to be reasonably similar. The standard k- $\varepsilon$ has a bit 
averaged after 5 cycles:

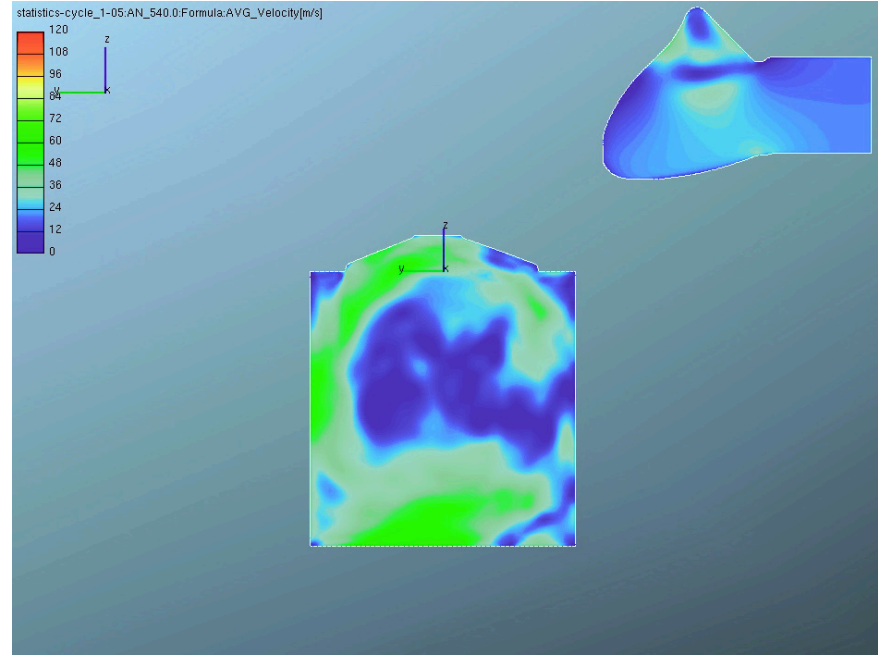

averaged after 15 cycles:

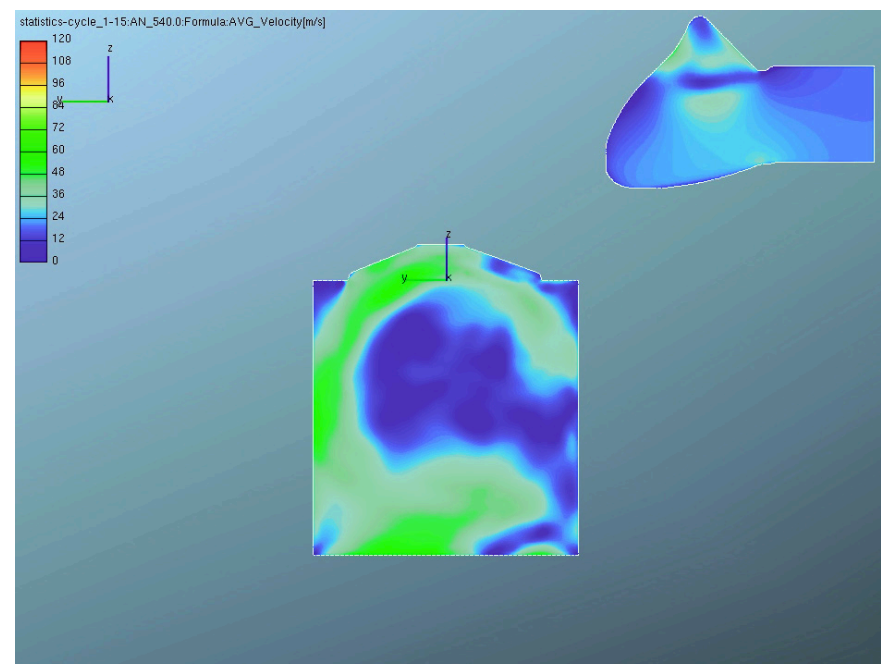

averaged after 35 cycles:

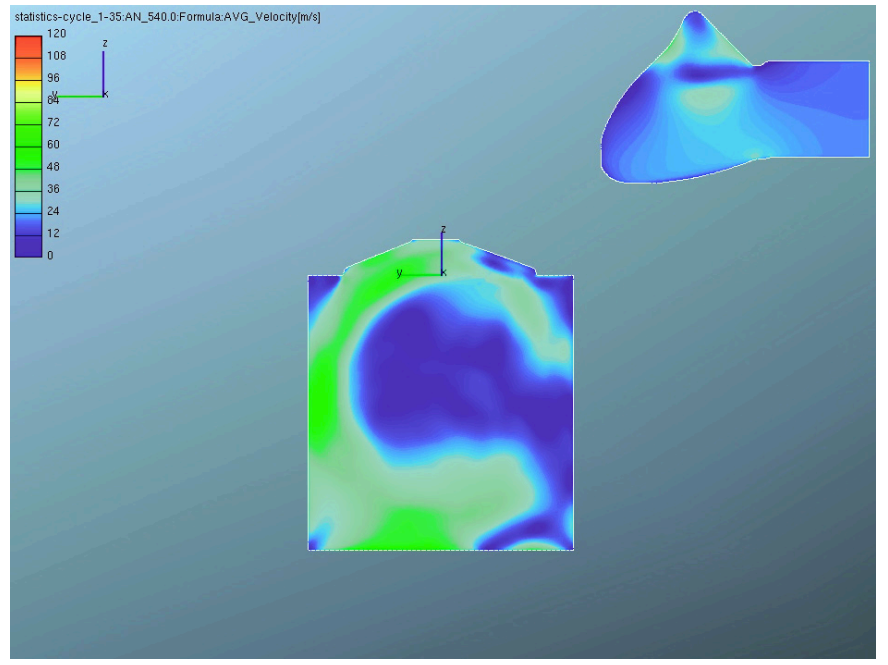

averaged after 10 cycles:

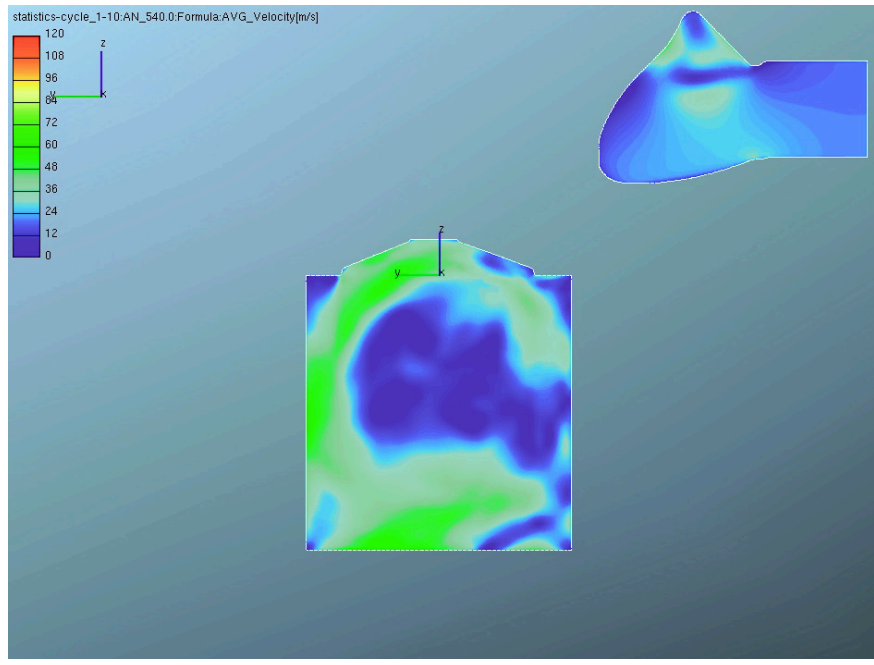

averaged after 25 cycles:

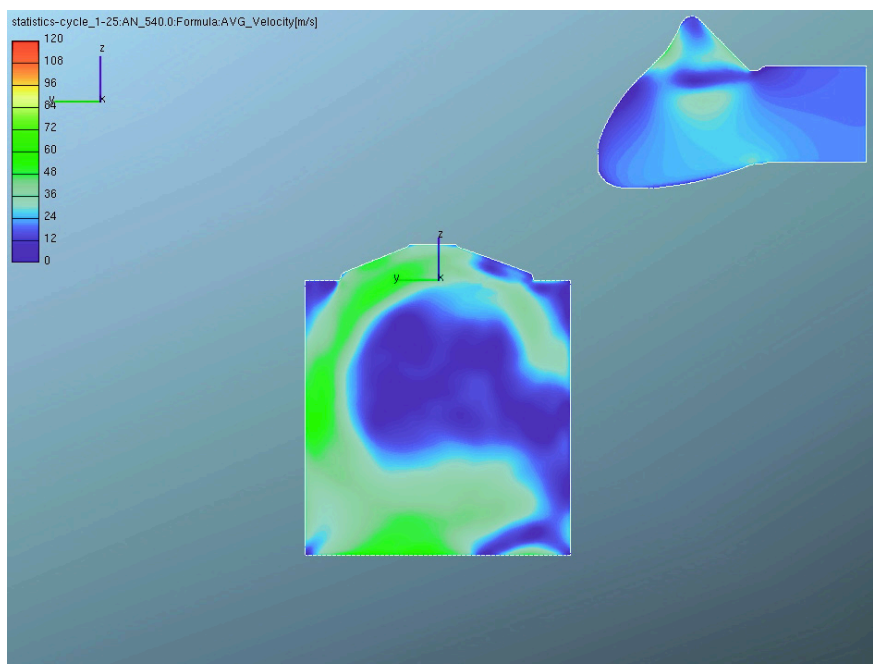

averaged after 45 cycles:

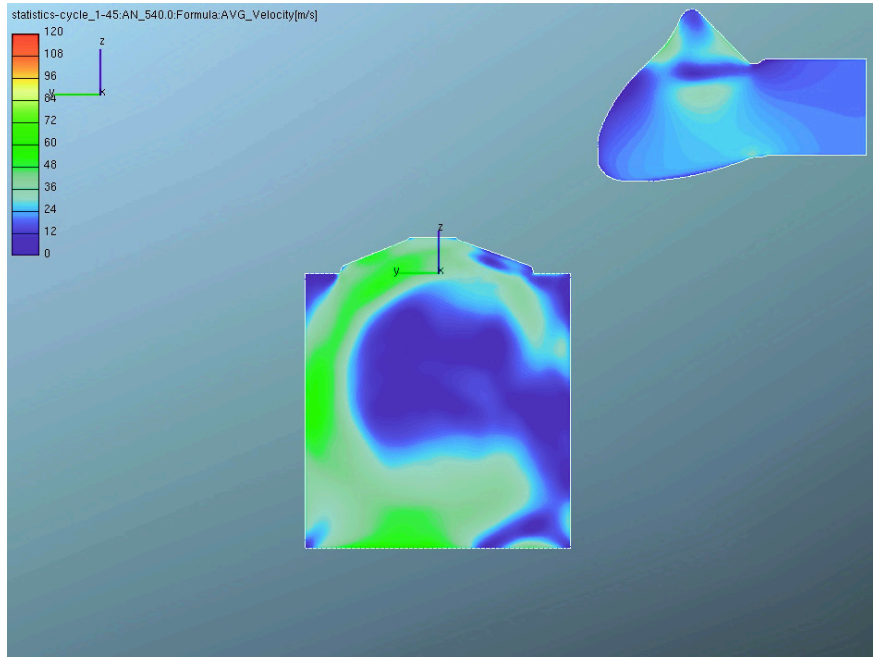

FIGURE 3: Statistical convergence of LES results regarding statistical moment of 1st order - velocity vector magnitude (blue color represents the value of $0 \mathrm{~m} / \mathrm{s}$, the red color corresponds to $120 \mathrm{~m} / \mathrm{s}$ ) at $540 \operatorname{deg} C A$, cutting plane $Y Z$, engine version $B$

OBRÁZEK 3: Statistická konvergence LES výsledků z hlediska momentů 1. řádu - velikost vektoru rychlosti (modrá barva odpovídá 0 m/s, červená $120 \mathrm{~m} / \mathrm{s})$ v $540 \operatorname{deg}(A$, rovina řezu $Y Z$, verze motoru $B$

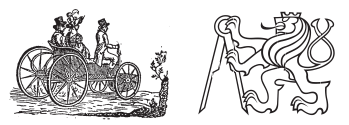


averaged after 5 cycles:

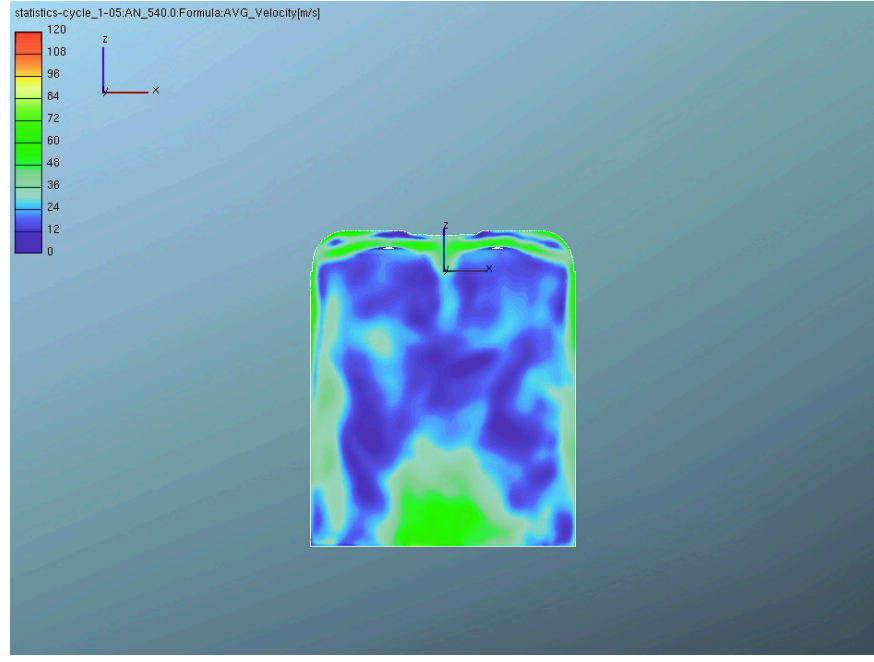

averaged after 15 cycles:

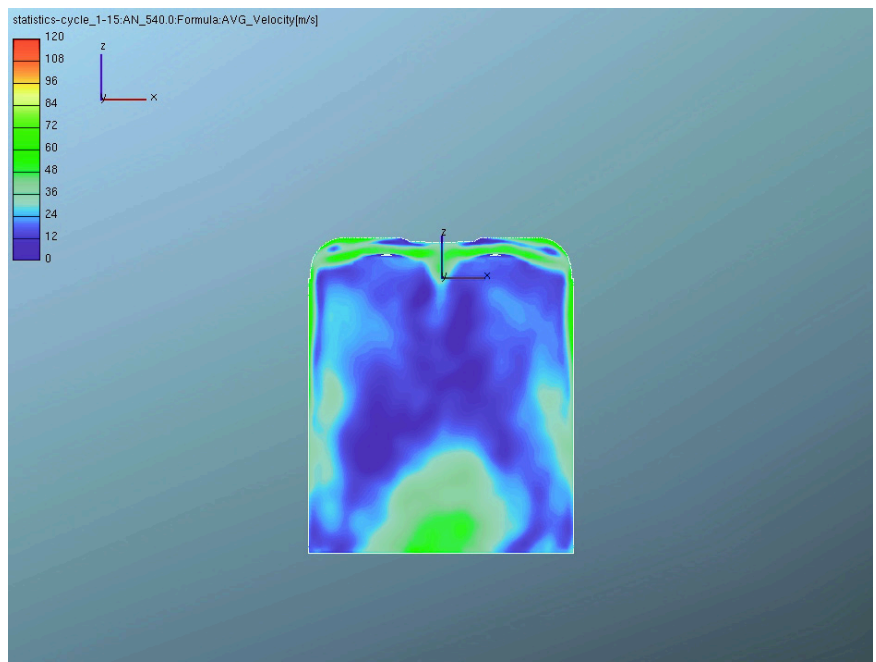

averaged after 35 cycles:

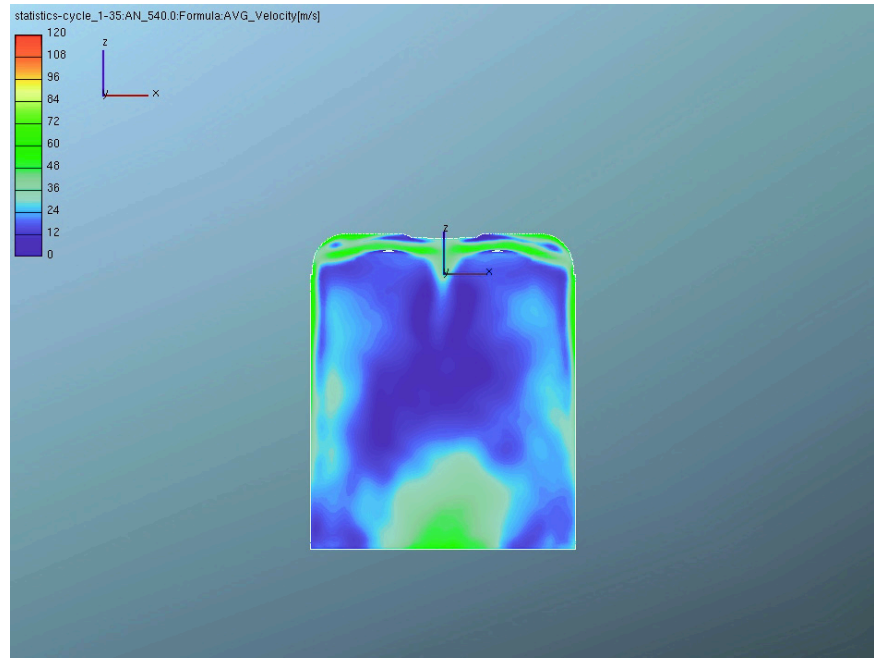

averaged after 10 cycles:

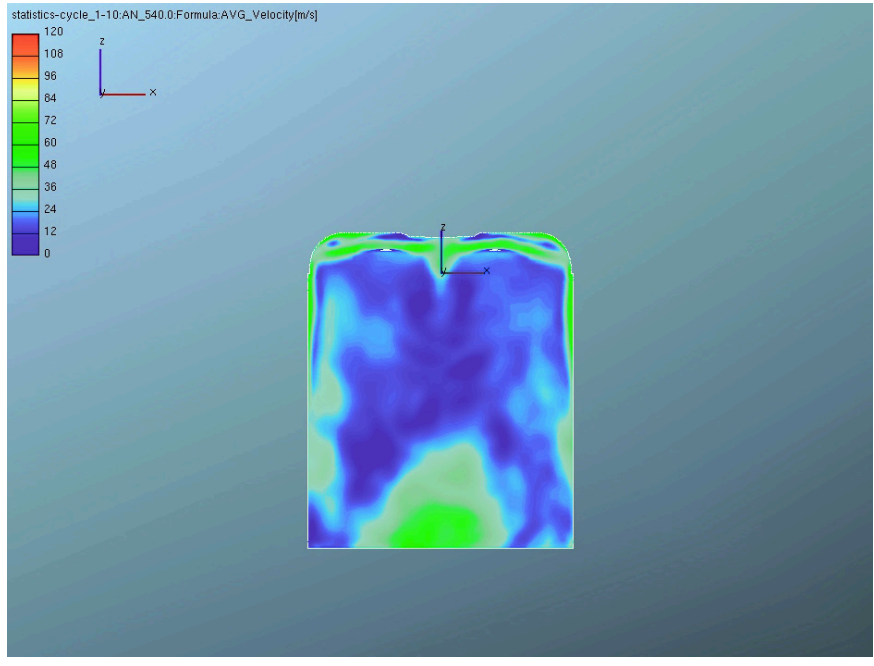

averaged after 25 cycles:

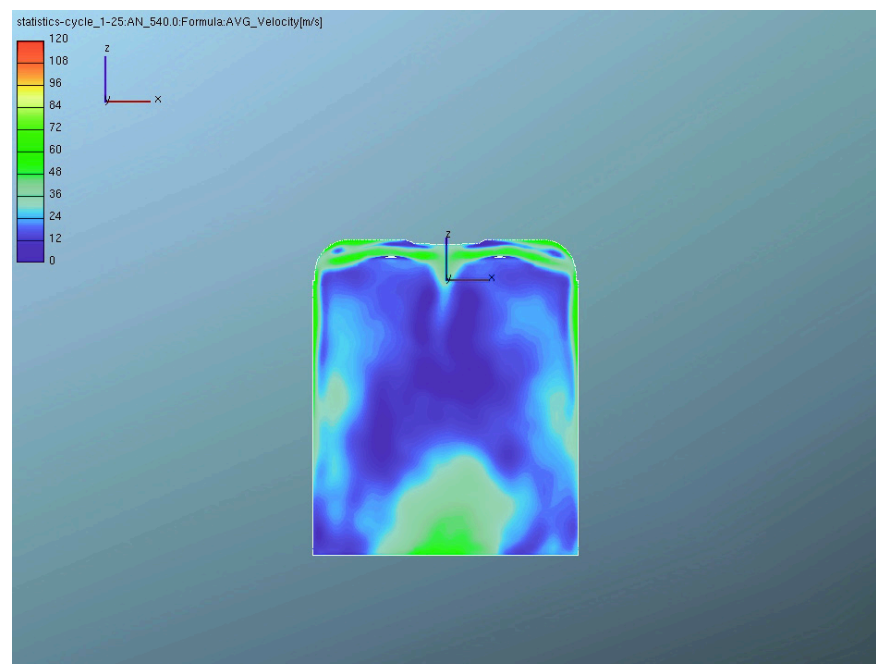

averaged after 45 cycles:

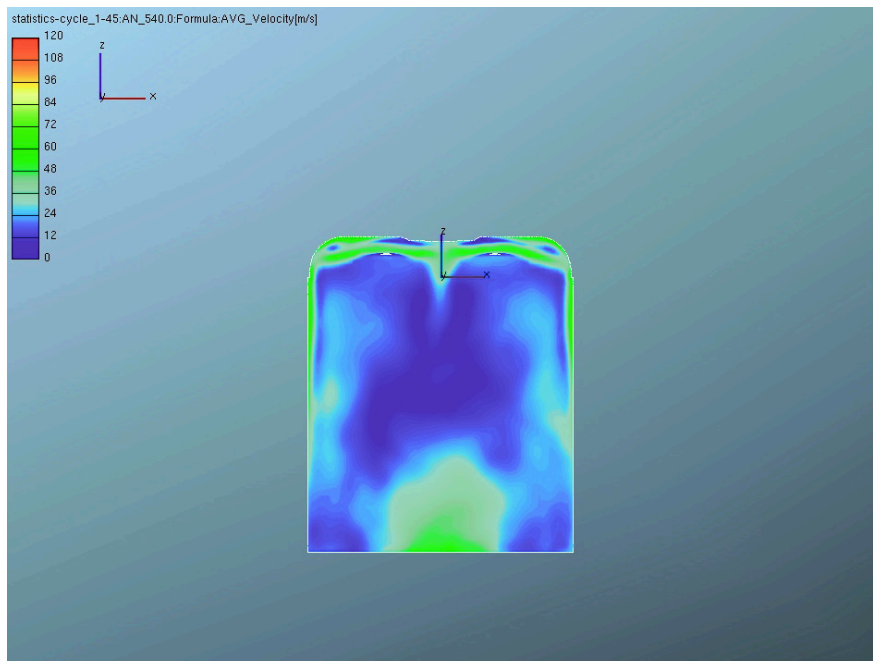

FIGURE 4: Statistical convergence of LES results regarding statistical moment of 1st order - velocity vector magnitude (blue color represents the value of $0 \mathrm{~m} / \mathrm{s}$, the red color corresponds to $120 \mathrm{~m} / \mathrm{s}$ ) at $540 \operatorname{deg} C A$, cutting plane $X Z$, engine version $B$

OBRÁZEK 4: Statistická konvergence LES výsledků z hlediska momentů 1. rádu - velikost vektoru rychlosti (modrá barva odpovídá $0 \mathrm{~m} / \mathrm{s}$, červená $120 \mathrm{~m} / \mathrm{s}$ ) v $540 \operatorname{deg} C A$, rovina řezu XZ, verze motoru B

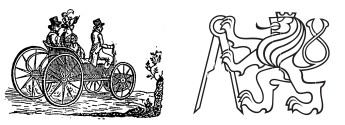


averaged after 5 cycles:

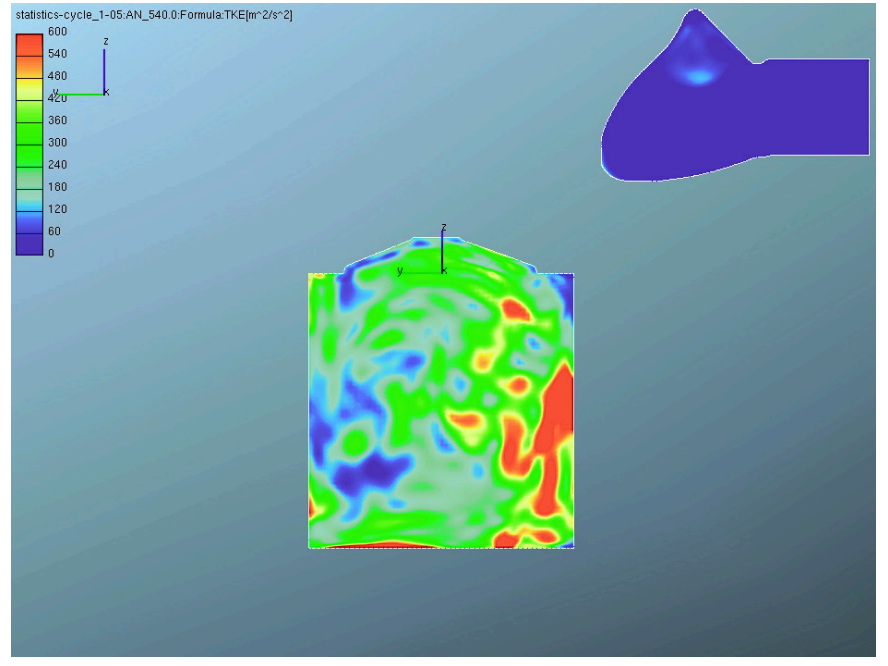

averaged after 15 cycles:

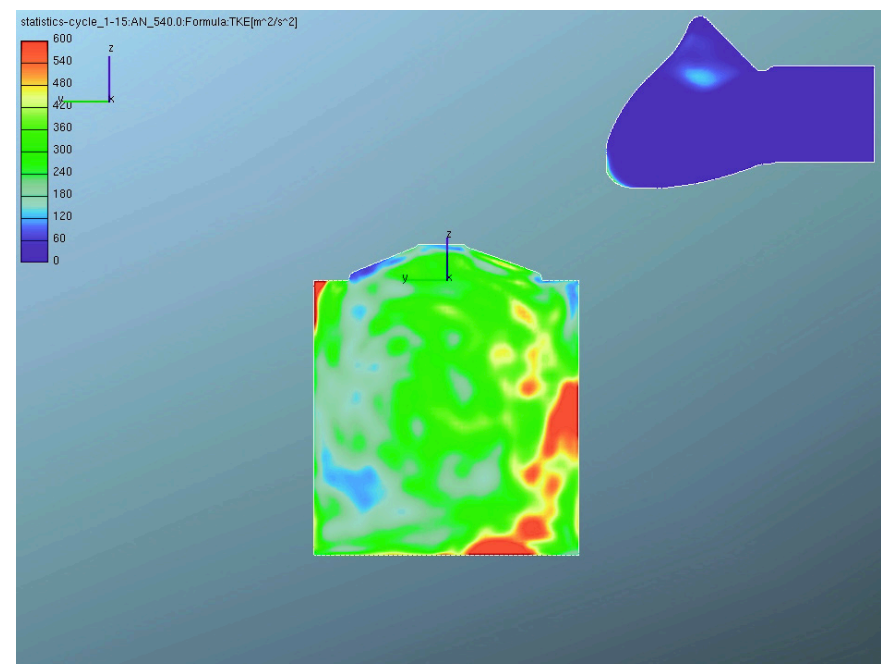

averaged after 35 cycles:

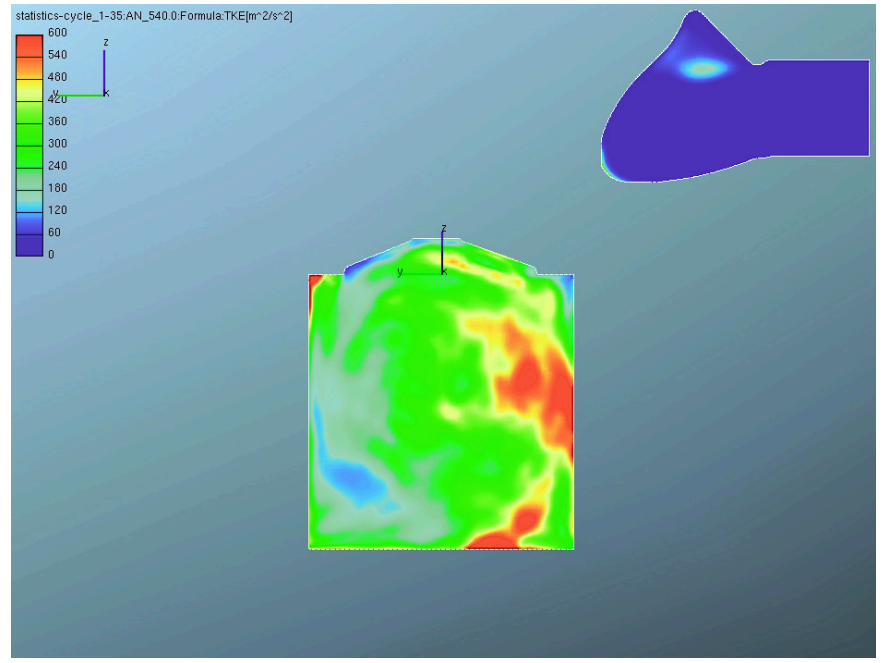

averaged after 10 cycles:

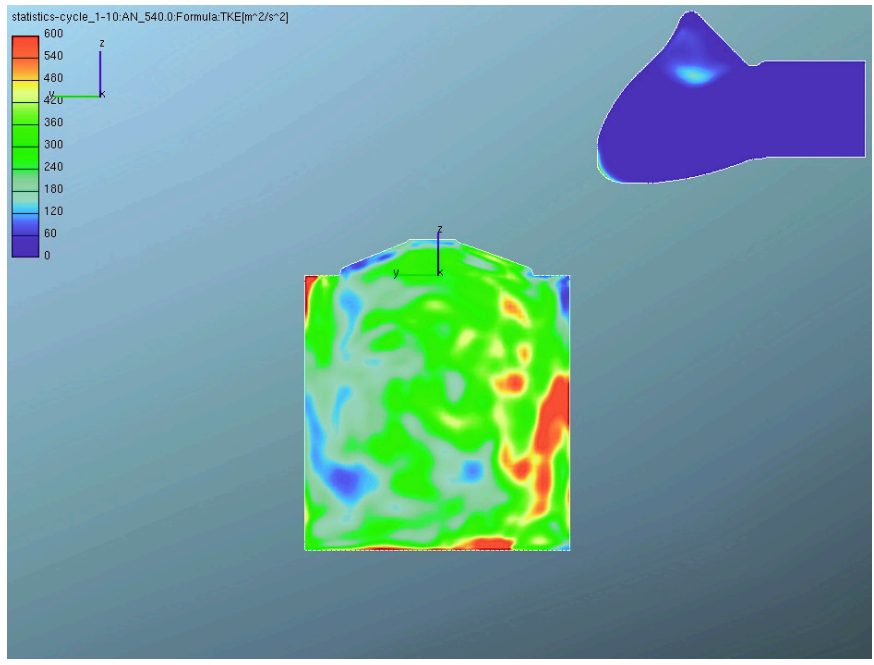

averaged after 25 cycles:

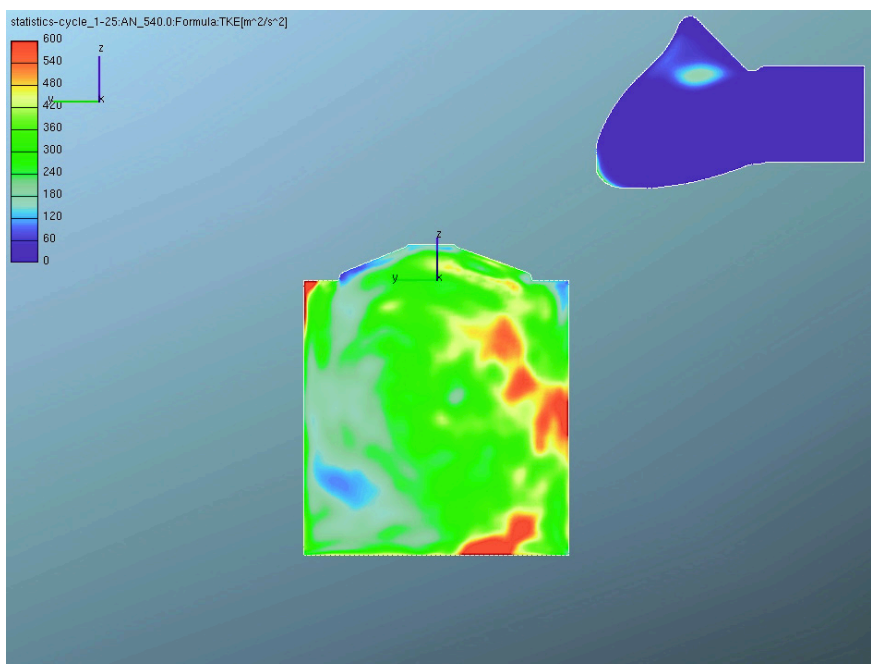

averaged after 45 cycles:

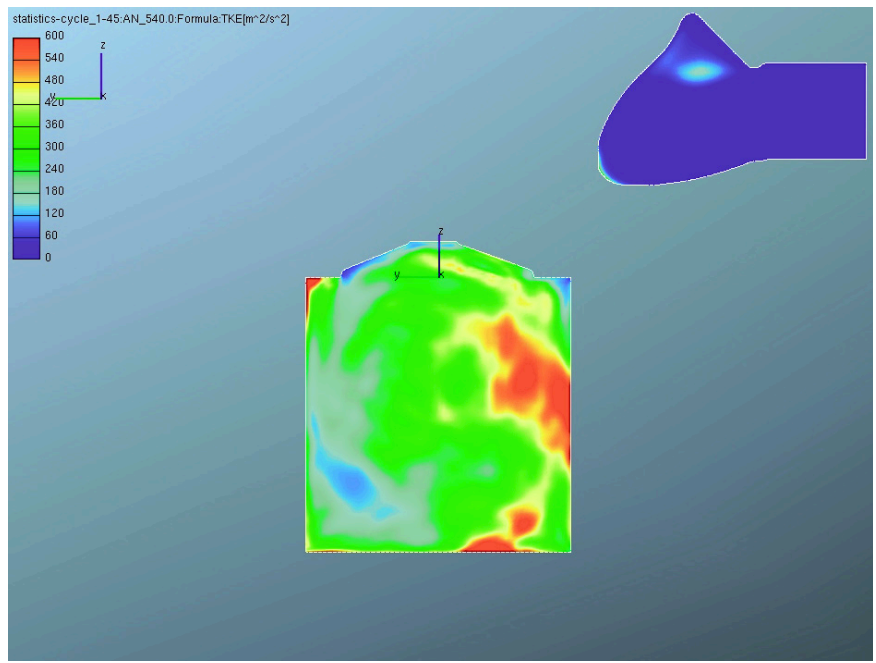

FIGURE 5: Statistical convergence of LES results regarding statistical moment of 2nd order - resolved fluctuation kinetic energy (blue color represents the value of $0 \mathrm{~m}^{2} / \mathrm{s}^{2}$, the red color corresponds to $600 \mathrm{~m}^{2} / \mathrm{s}^{2}$ ) at 540 degCA, cutting plane $Y Z$, engine version $B$

OBRÁZEK 5: Statistická konvergence LES výsledků z hlediska momentů 2. řádu - výpočtem zachycená kinetická energie fluktuací (modrá barva odpovídá $0 \mathrm{~m}^{2} / \mathrm{s}^{2}$, červená $600 \mathrm{~m}^{2} / \mathrm{s}^{2}$ ) v 540 degCA, rovina řezu YZ, verze motoru B 
averaged after 5 cycles:

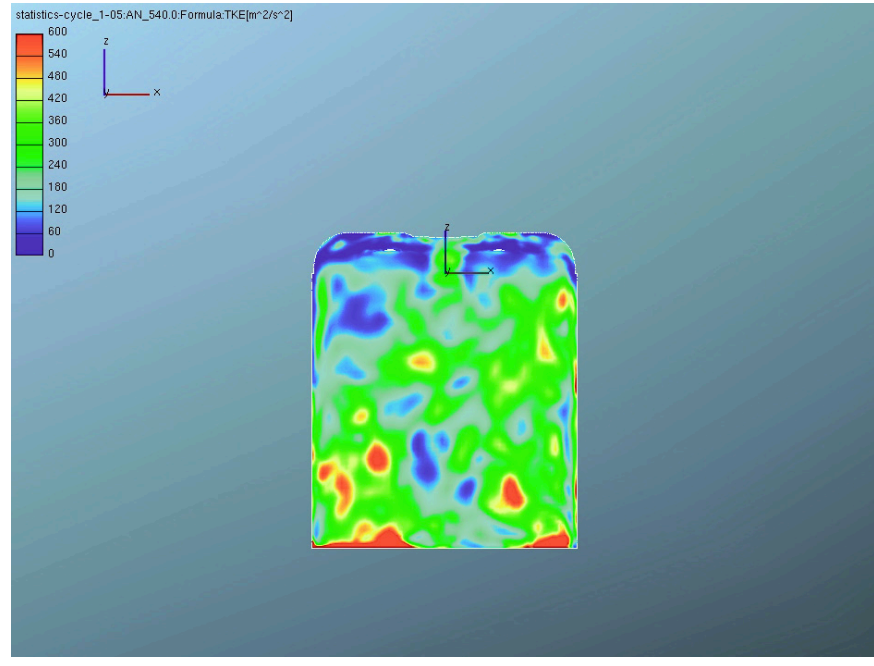

averaged after 15 cycles:

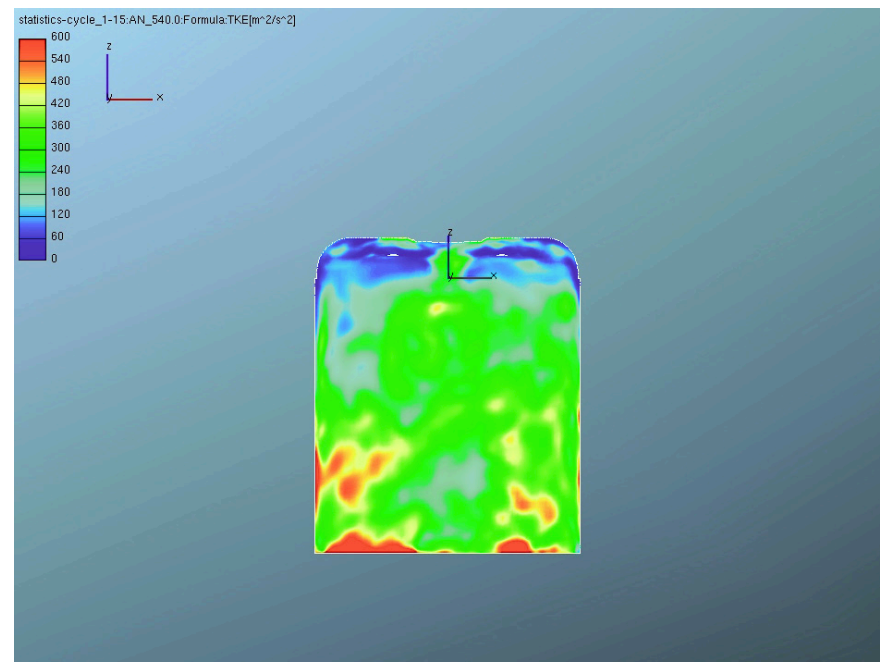

averaged after 35 cycles:

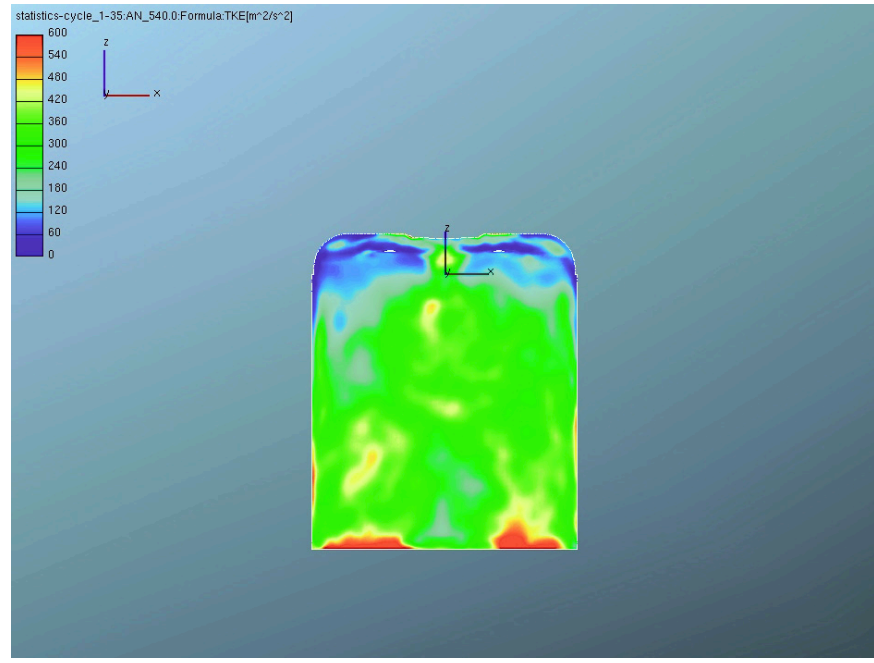

averaged after 10 cycles:

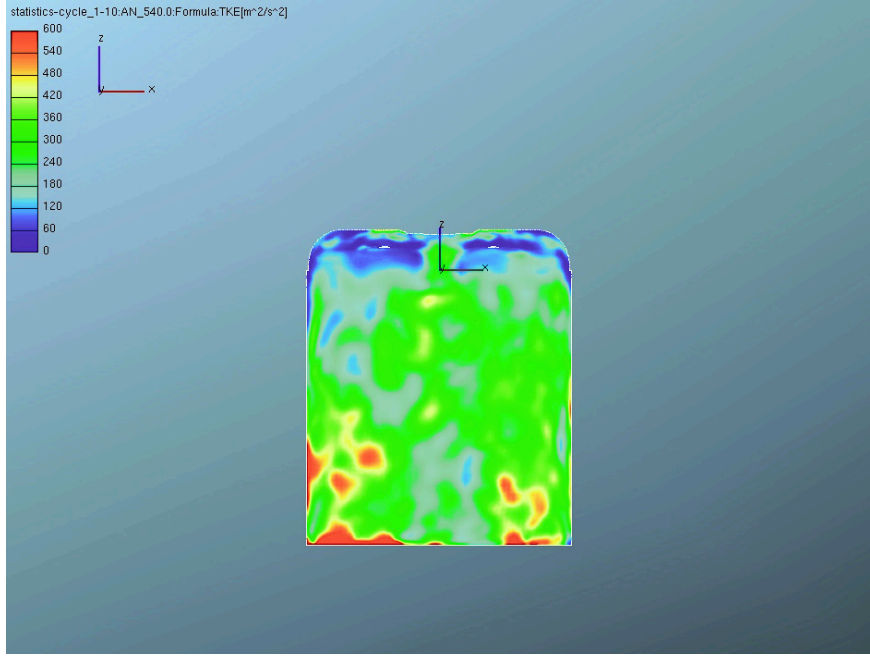

averaged after 25 cycles:

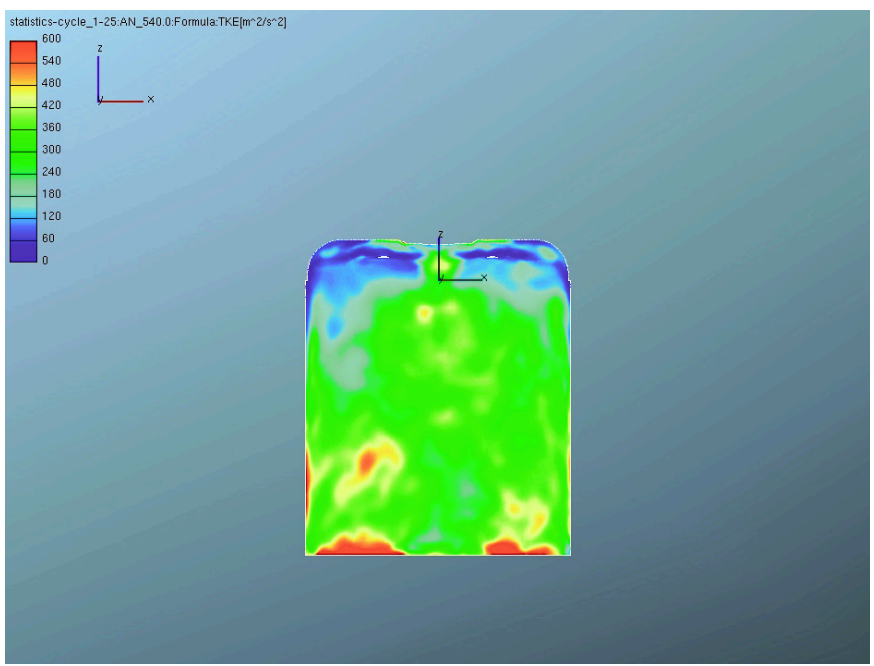

averaged after 45 cycles:

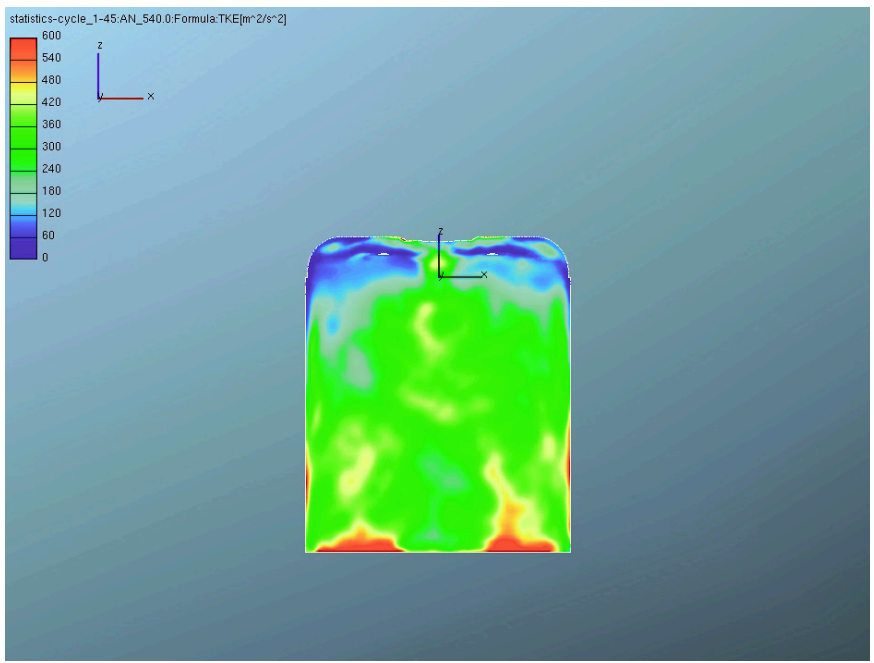

FIGURE 6: Statistical convergence of LES results regarding statistical moment of 2nd order - resolved fluctuation kinetic energy (blue color represents the value of $0 \mathrm{~m}^{2} / \mathrm{s}^{2}$, the red color corresponds to $600 \mathrm{~m}^{2} / \mathrm{s}^{2}$ ) at $540 \operatorname{degCA}$, cutting plane $\mathrm{XZ}$, engine version $\mathrm{B}$

OBRÁZEK 6: Statistická konvergence LES výsledků z hlediska momentů 2. rádu - výpočtem zachycená kinetická energie fluktuací (modrá barva odpovídá $0 \mathrm{~m}^{2} / \mathrm{s}^{2}$, červená $\left.600 \mathrm{~m}^{2} / \mathrm{s}^{2}\right)$ v $540 \mathrm{deg} C A$, rovina řezu $\mathrm{XZ}$, verze motoru $B$

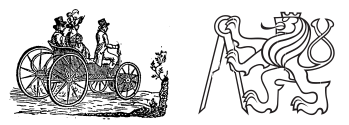


LES - averaged velocity magnitude:

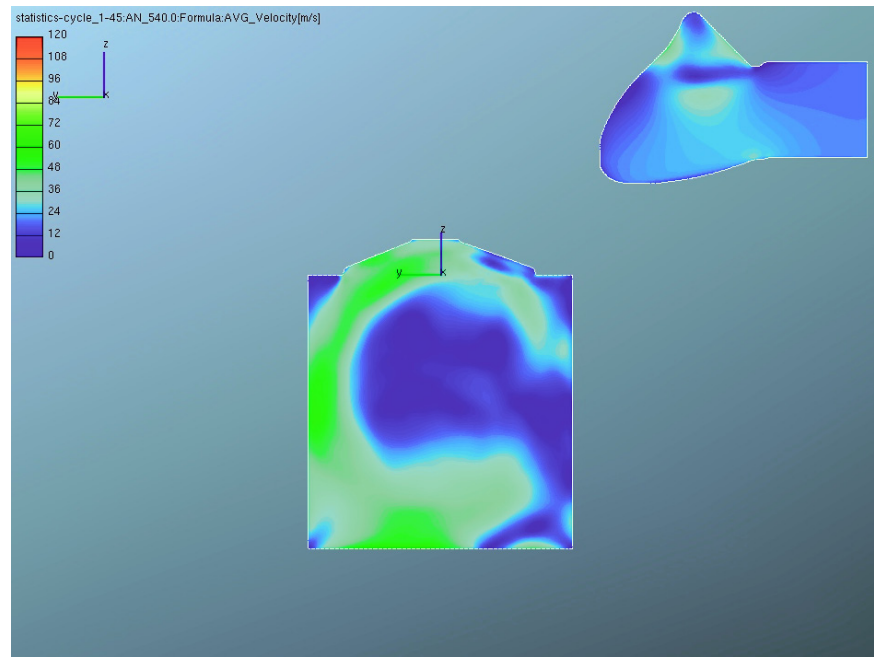

RANS $(k-\zeta-f)$ - averaged velocity magnitude:

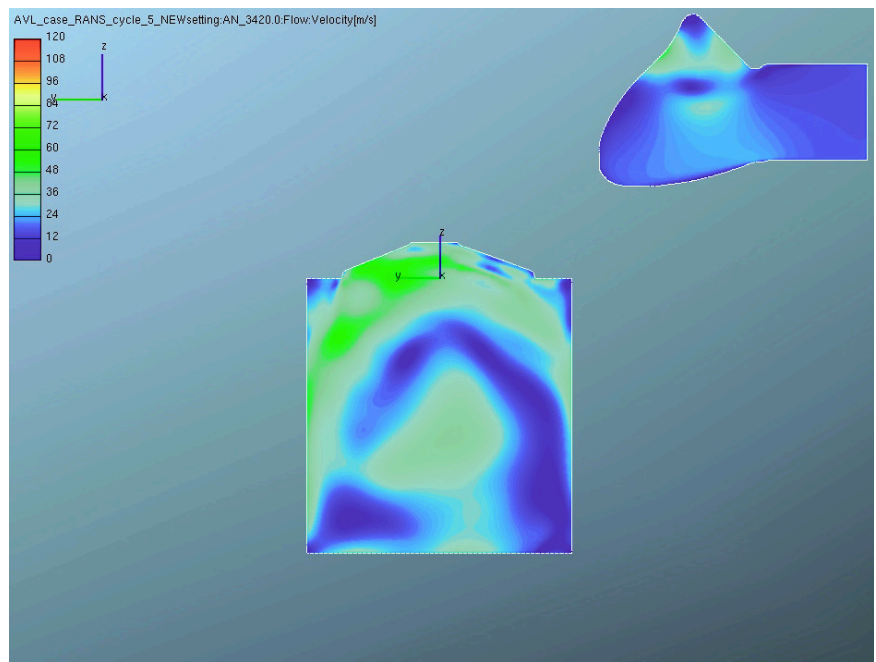

RANS $(k-\varepsilon)$ - averaged velocity magnitude:

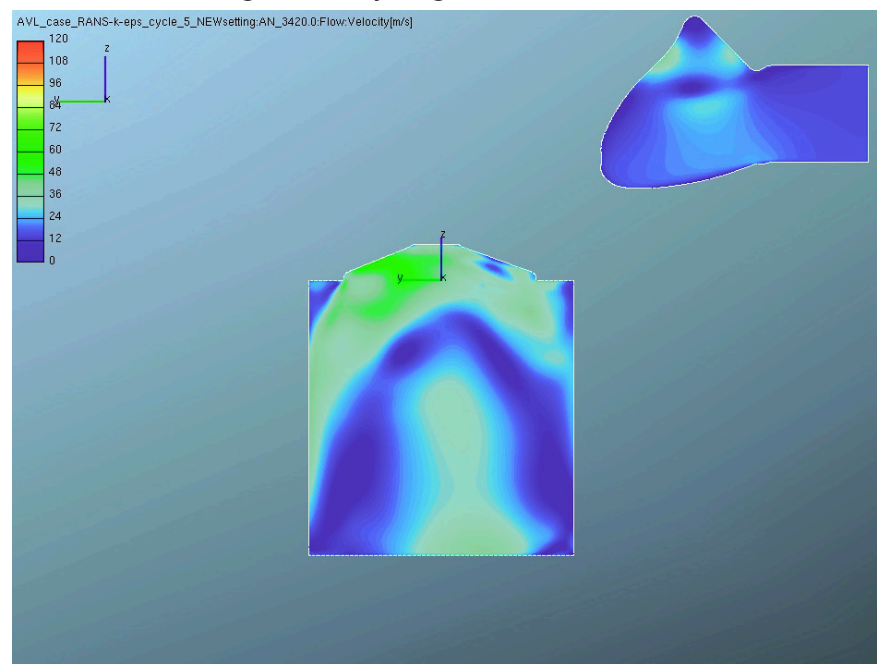

LES - RFKE:

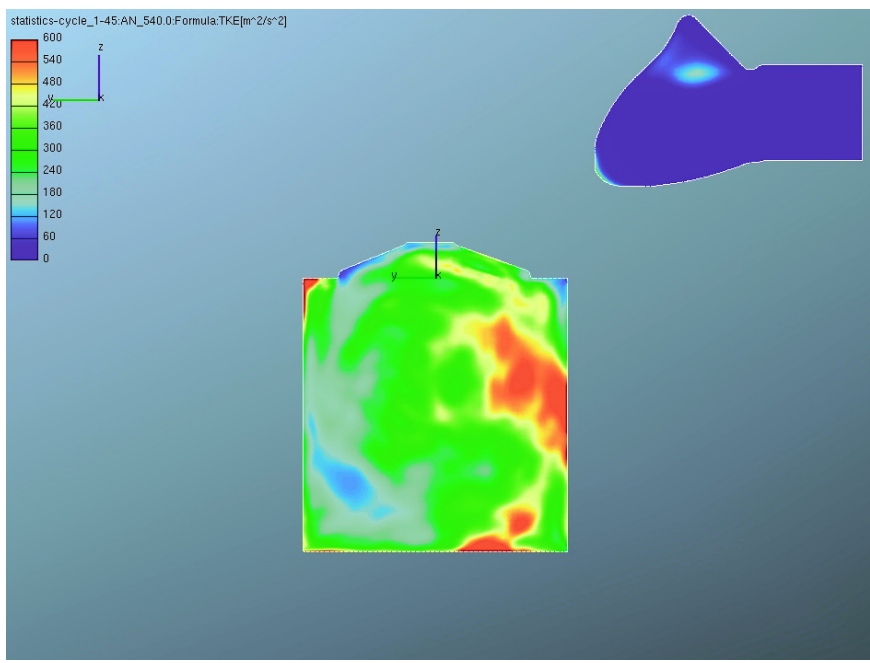

RANS $(k-\zeta-f)-$ RFKE:

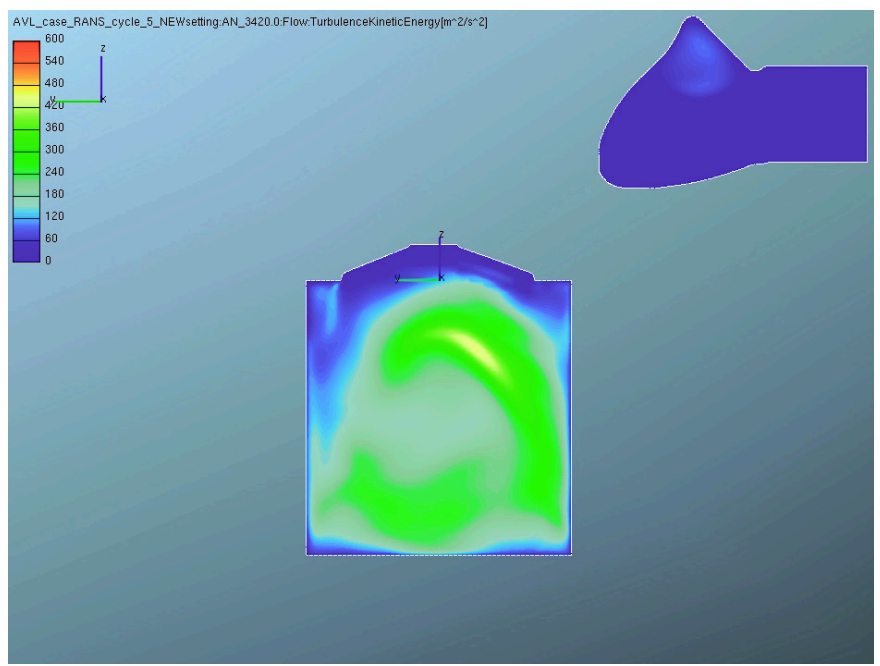

RANS $(k-\varepsilon)-$ RFKE:

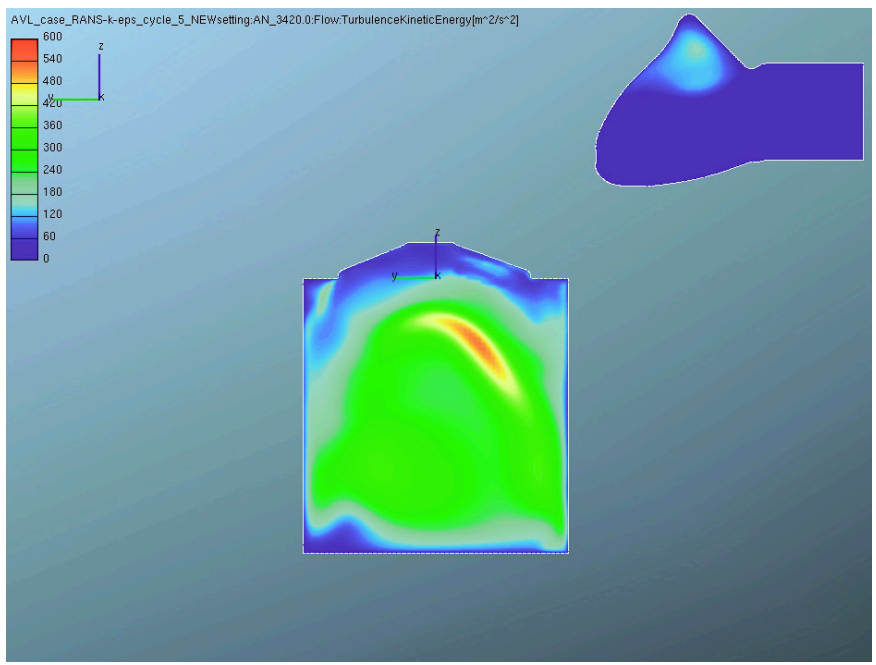

FIGURE 7: Comparison of different turbulence models - average velocity vector magnitude (left column) and resolved fluctuation kinetic energy (right column) at $540 \operatorname{degCA}$, cutting plane $\mathrm{YZ}$, engine version B

OBRÁZEK 7: Porovnání různých modelů turbulence - velikost průměrného vektoru rychlosti (levý sloupec) a výpočtem zachycená kinetická energie fluktuací (pravý sloupec) v 540 degCA, rovina řezu YZ, verze motoru B

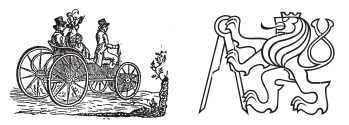


LES - averaged velocity magnitude:

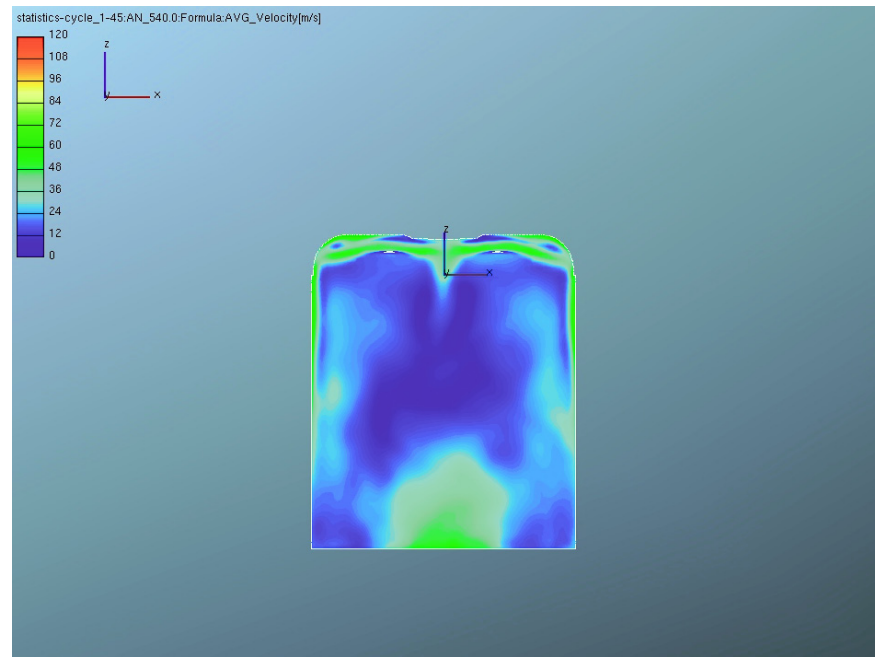

RANS $(k-\zeta-f)$ - averaged velocity magnitude:

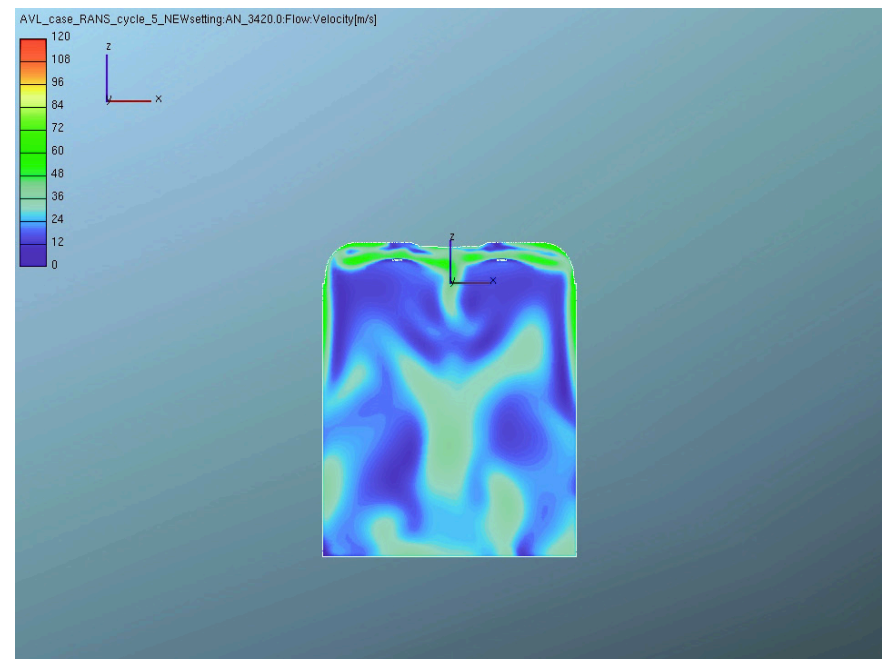

RANS $(k-\varepsilon)$ - averaged velocity magnitude:

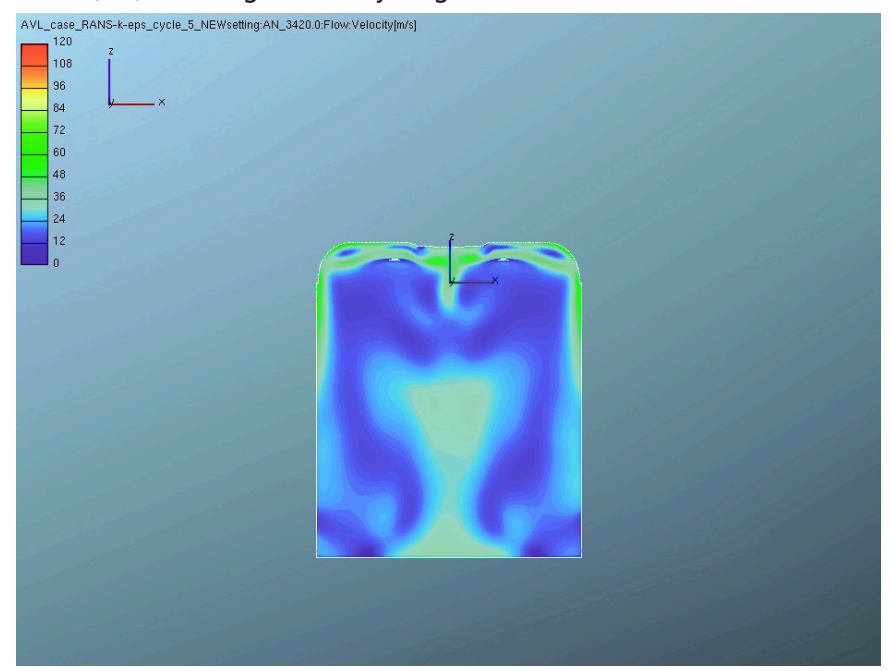

LES - averaged velocity RFKE:

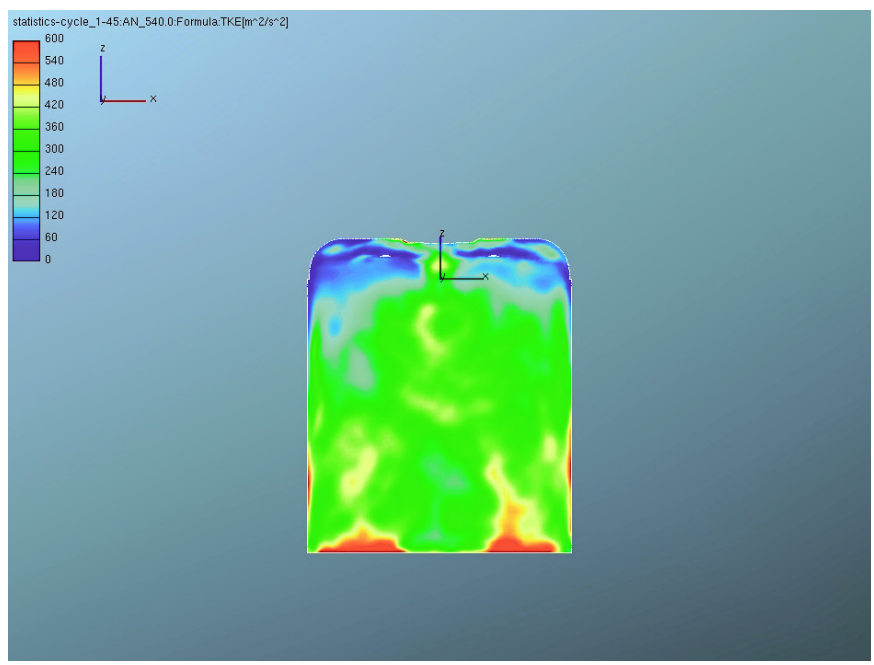

RANS (k- $\zeta-f)$ - averaged velocity RFKE:

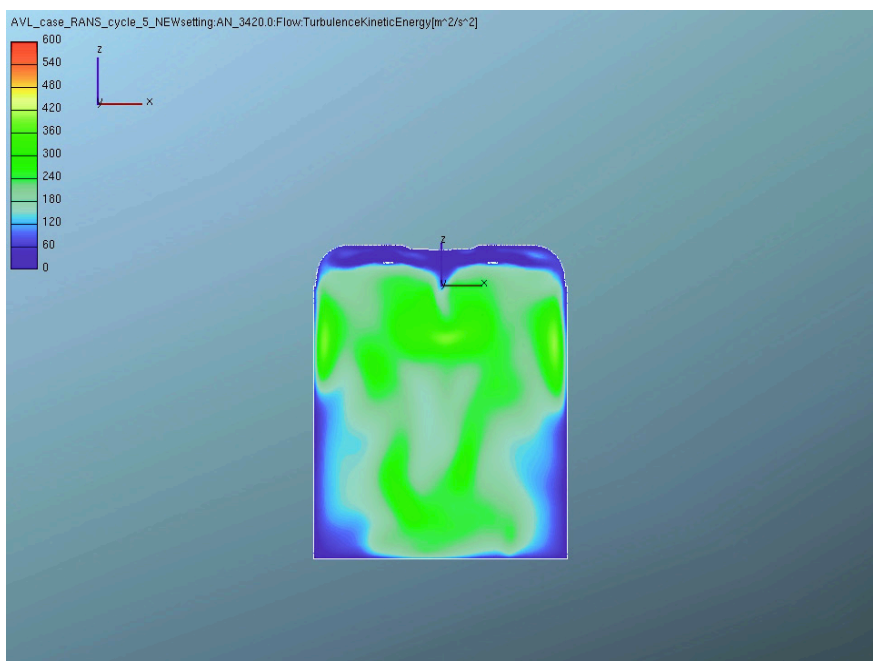

RANS $(k-\varepsilon)$ - averaged velocity RFKE:

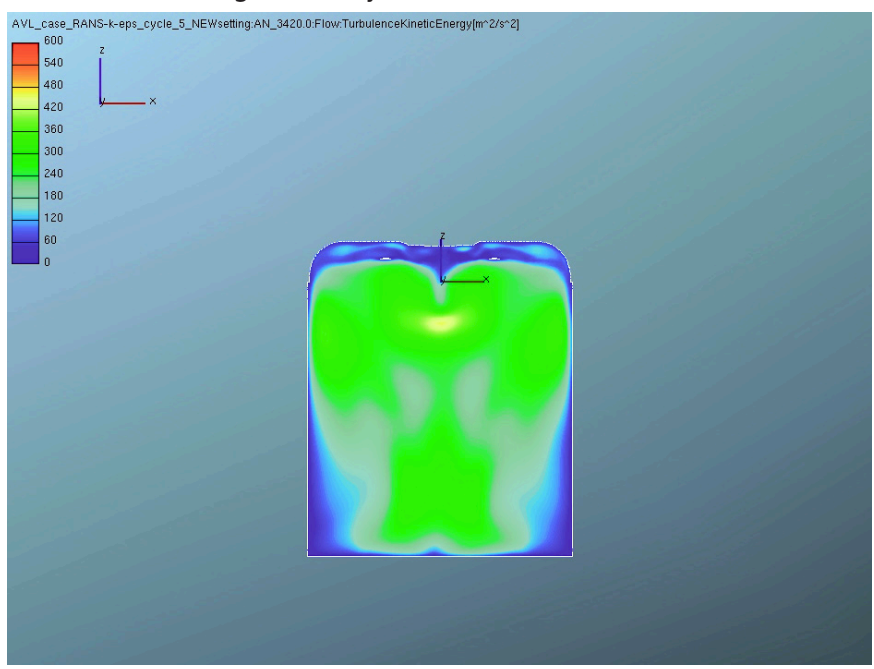

FIGURE 8: Comparison of different turbulence models - average velocity vector magnitude (left column) and resolved fluctuation kinetic energy (right column) at $540 \operatorname{deg} C A$, cutting plane $\mathrm{XZ}$, engine version $\mathrm{B}$

OBRÁZEK 8: Porovnání různých modelů turbulence - velikost průměrného vektoru rychlosti (levý sloupec) a výpočtem zachycená kinetická energie fluktuací (pravý sloupec) v $540 \operatorname{degCA}$, rovina řezu XZ, verze motoru B

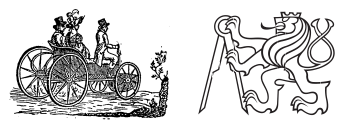


higher peaks of turbulence kinetic energy. Another feature of the standard $k-\varepsilon$ model is that its solution tends to predict symmetry better when compared with the $k-\zeta-f$. In this sense, it is similar to the averaged LES approach.

The results shown in Figure 3, 4, 5 and 6 correspond to detailed local data based on 3-D CFD. It is usually interesting to study such data at some special locations. For the case of ICE, such location is typically a spark plug one - to be more precise, it is the gap between spark electrodes which is of high interest as this location is crucial in terms of early flame kernel development. When using LES, the mesh is relatively fine. Moreover, the mesh is usually refined near the spark plug. Hence, the location of interest is covered by many mesh cells. Hence, when studying local properties at spark plug, the information from many cells needs to processed. The easiest approach is to calculate mass-averaged value of any intensive property (e.g. velocity, kinetic energy) - c.f. Equation 4, the value of $F_{a v g, V}$ - and then to apply averaging procedure. Such information actually corresponds to average value at the spark plug in terms of both statistical average and space/mass average. Example of such result is shown in Figure 9. The data shown in this figure confirm (again) that using 10 cycles for averaging procedure can lead to nonnegligible errors (compare red and blue curves in Figure 9).

Similar example is presented in Figure 10 - it (again) concerns values at spark plug. In this particular case, different curves are plotted. First, the average value is shown. Second, the estimate of lower/upper limit is presented - it is based on average value which is lowered/increased by RMS value (the authors are aware that these particular values have no obvious statistical meaning - the applied estimate is based on assumption that any instantaneous value can be decomposed into average one and fluctuating one). Third, 10 instantaneous values are plotted. Based on that, there are a lot of curves in the figures. However, it shows nicely that there are phases during 4-stroke engine cycle when CCV is strong (late intake stroke, whole compression stroke including ignition timing) while there are also phases when CCV is surprisingly low (late exhaust stroke, early intake stroke). This figure also confirms that oscillations, which can be calculated as difference between actual value and average one (c.f. $[6,7]$ for Reynolds/Favre averaging), look quite random - however, they are not really random as basic conservation laws (mass, momentum, energy) have to be satisfied. Finally, the presented data (in Figure 10) also confirms that the estimate of interval, where it is very likely that any instantaneous value is supposed to fit in, is reasonably predicted by using RMS value to be added/subtracted to average value (the interval is $<$ AVG-RMS; AVG+RMS >).

Finally, integral (global) values are presented in Figure 11 and 12. Such values represent the status of the whole combustion chamber (e.g., total in-cylinder mass in Figure 11 or combustion progress in time domain in Figure 12). This kind of information is very important, especially when comparing with experimental data or when calibrating system simulation tools (which are based on 0-D/1-D approach). Data shown in Figure 11 correspond to typical important information in terms of in-cylinder thermodynamic status at time of spark ignition. In-cylinder mass CCV is relatively low. On the other hand, CCV of total kinetic energy is high. The same applies to CCV of in-cylinder air excess while EGR CCV is not that strong. Concerning air excess, the CCV is driven by variations of gas exchange phase - this effect is magnified by the fact that there is high internal EGR (due to high valve overlap) and that the overall control strategy is to have a lean mixture. Hence, when there is higher internal EGR, there is also more free oxygen from previous cycle, which influences total air excess. However, not only global (average) values are important - the level of homogeneity is important as well. In this sense, it seems that mixture is reasonably well homogeneous as the value of uniformity index is high. Regarding the data from Figure 12, it shows significant CCV of combustion related parameters. This is in-line with experimental evidence (c.f. [4]). Moreover, dependency of duration of initial/main combustion phase with respect to incylinder average specific kinetic energy (due to low CCV of in-cylinder mass, this value is proportional to total in-cylinder kinetic energy). As expected, the initial phase (duration from 0 to $10 \%$ of burned fuel mass) is quite random while the main phase (usually called as 'rapid burning phase' - duration from 10 to $90 \%$ of burned fuel mass) shows relatively strong correlation with respect to total in-cylinder kinetic energy. That statement was also expected as the value (of total kinetic energy) consists of 2 parts: average kinetic energy (in terms of ensemble averaging) and RFKE. As RFKE is supposed to be dominated by turbulence kinetic energy, the higher value of total in-cylinder kinetic energy actually means higher value of turbulence kinetic energy which leads to faster propagation of turbulent flame front - c.f. [13].

\section{CONCLUSION}

The paper describes the procedure to process large amount of 3-D CFD data in terms of CCV. The procedure is based on statistical analysis and it is applied locally in every mesh cell. However, application of averaging procedure leads to 
velocity component $\mathrm{U}$ :

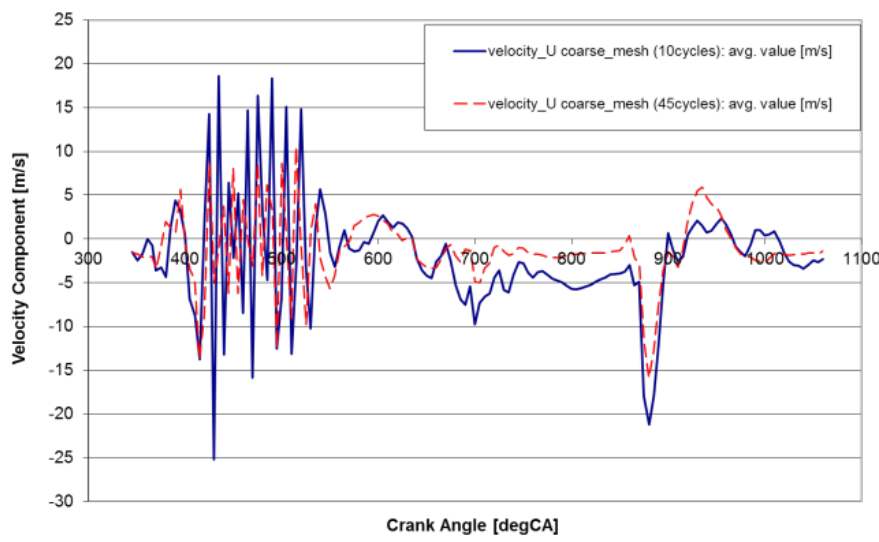

velocity component $\mathrm{V}$ :

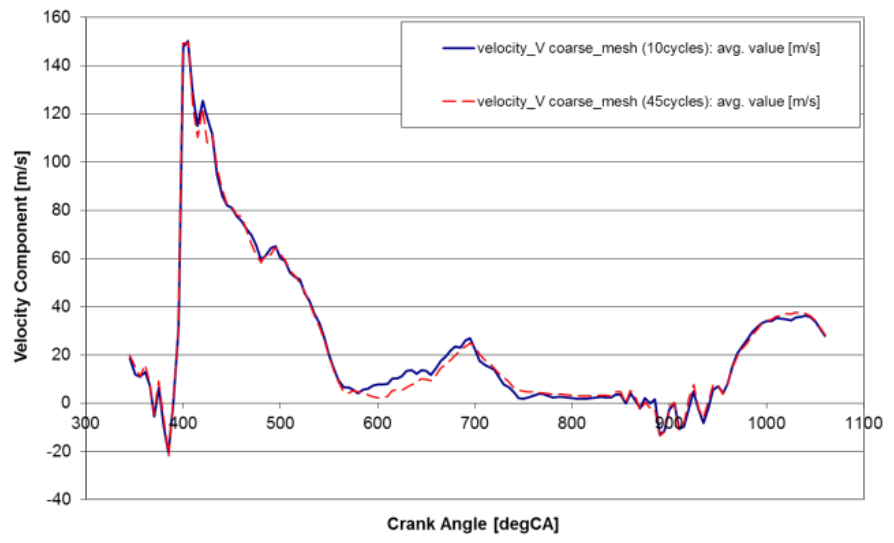

velocity component W:

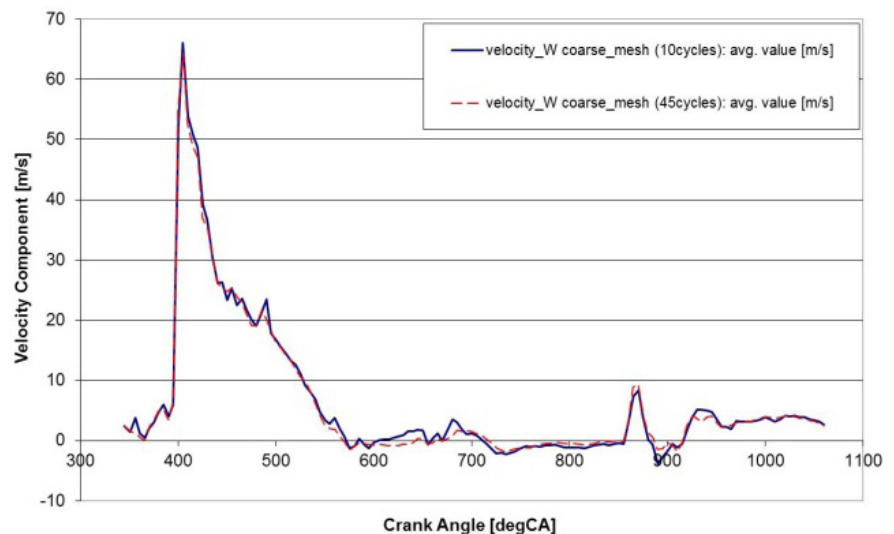

RMS of velocity component $\mathrm{U}$ :

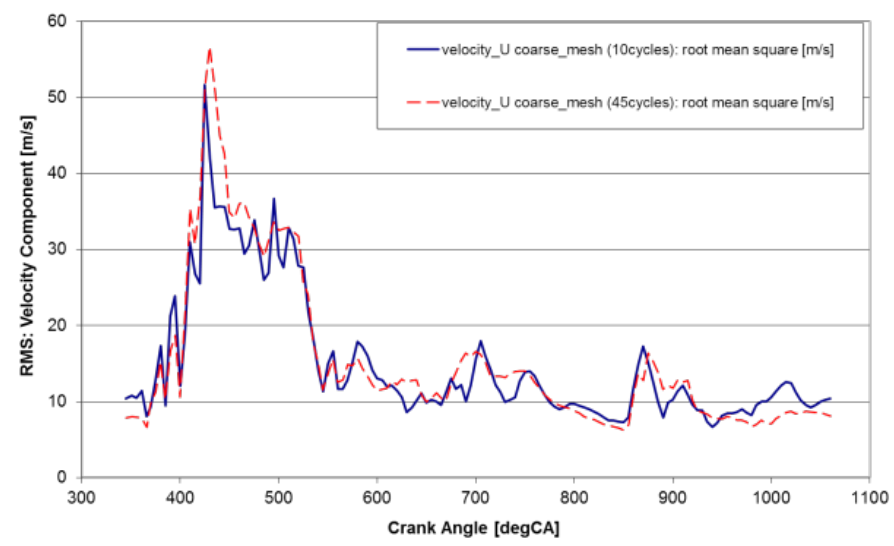

RMS of velocity component V:

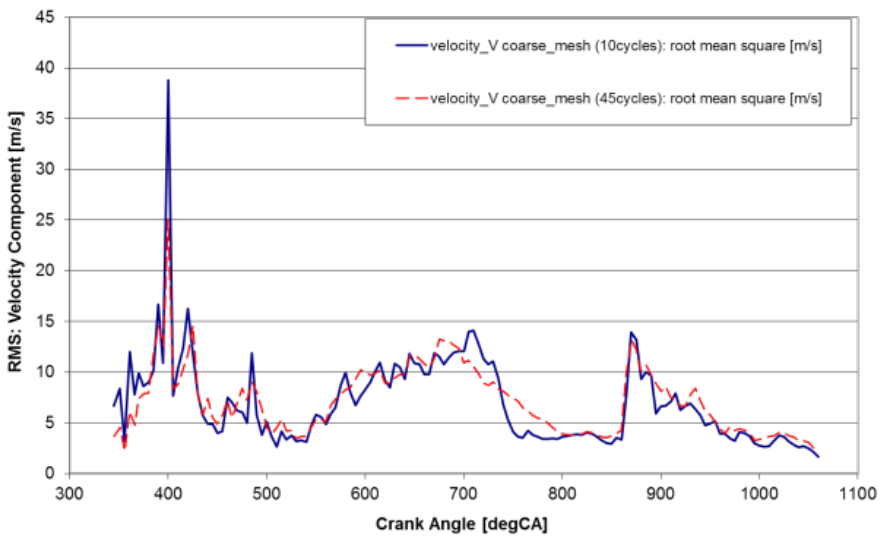

RMS of velocity component W:

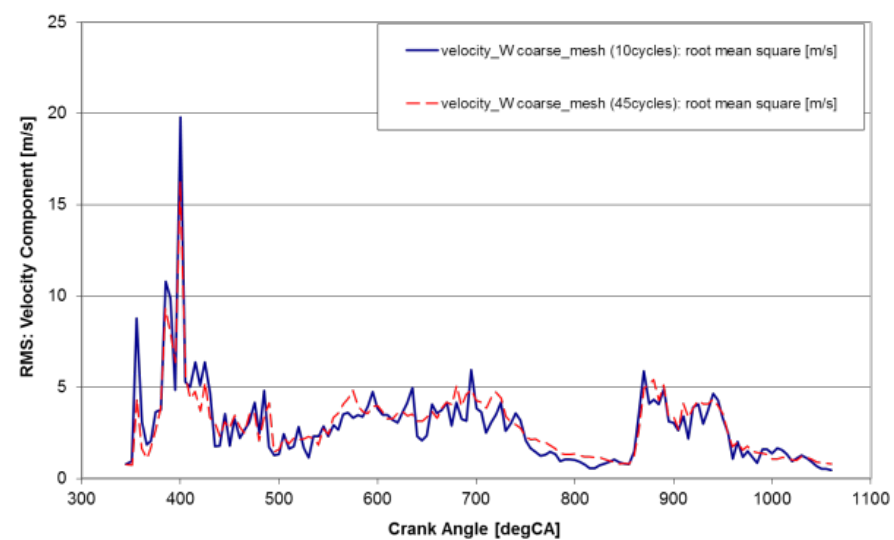

FIGURE 9: Statistical convergence of LES results regarding statistical moment of 1 st order (left column: velocity vector components) and 2 nd order (right column: RMS of velocity vector components) at spark plug location, engine version B.

OBRÁZEK 9: Statistická konvergence LES výsledků z hlediska momentů 1. řádu (levý sloupec: složky vektoru rychlosti) a 2. rádu (pravý sloupec: RMS složek vektoru rychlosti) v místě zapalovací svíčky, verze motoru B. 
velocity component $\mathrm{U}$ :

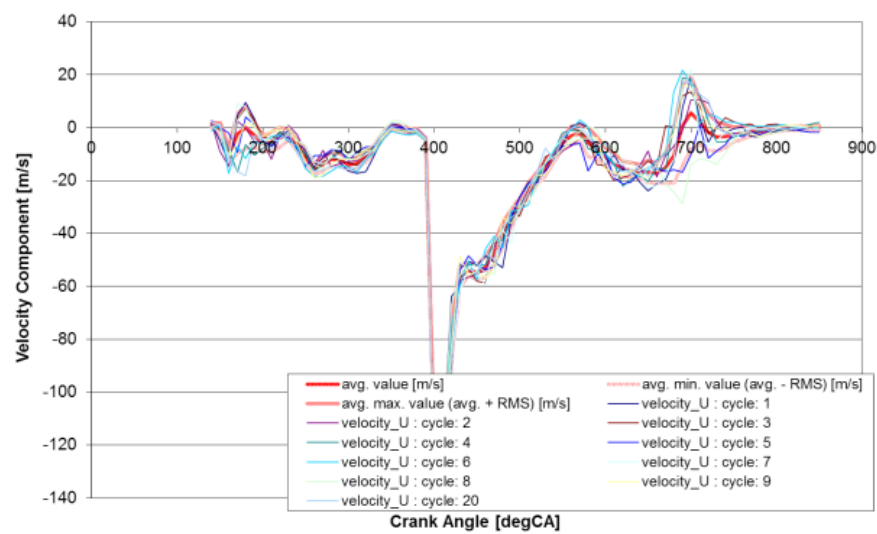

velocity component W:

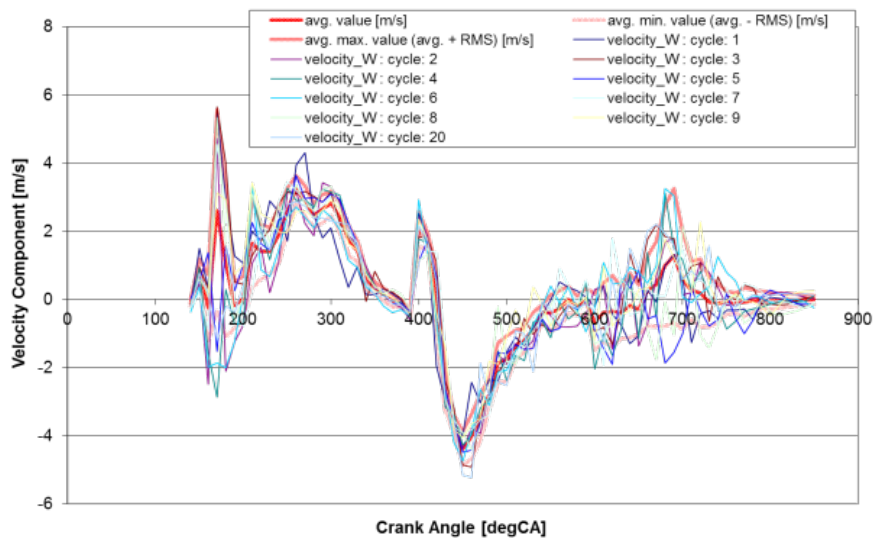

velocity component $\mathrm{V}$ :

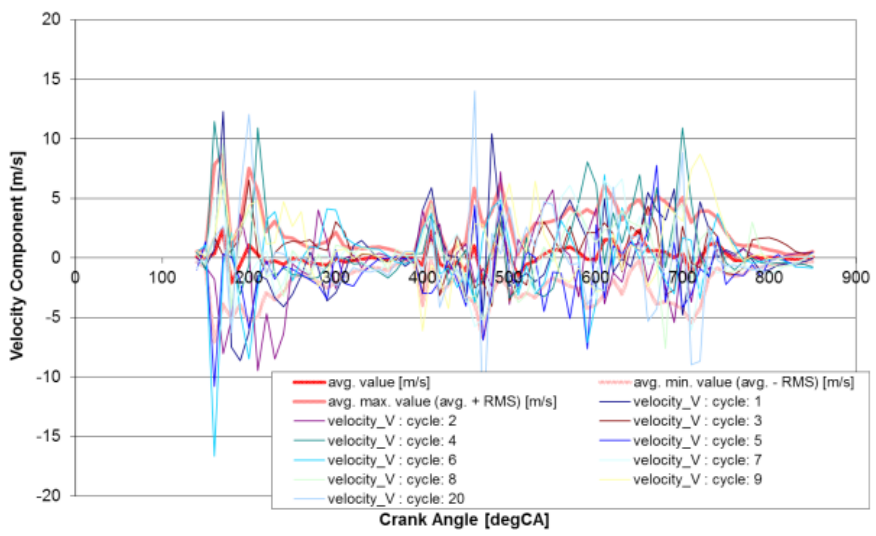

equivalence ratio:

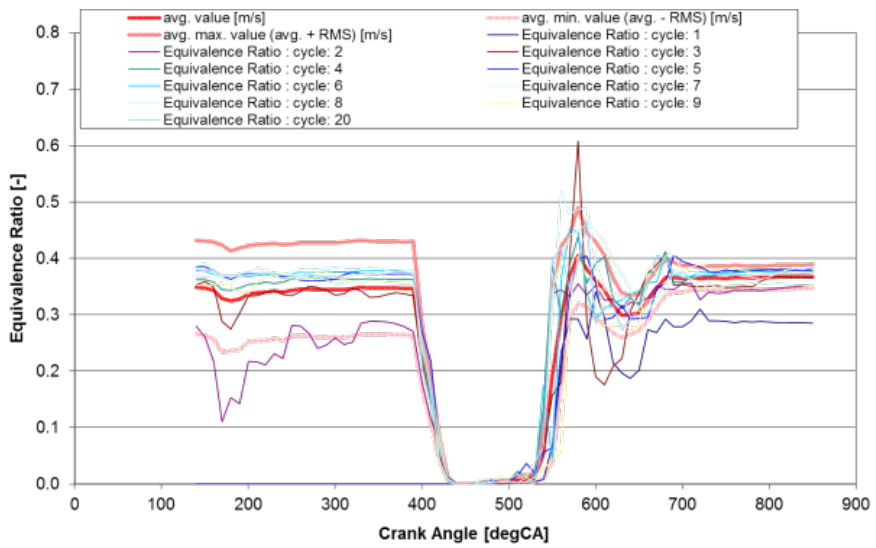

FIGURE 10: Local values (velocity vector components and equivalence ratio) at spark plug location during the whole engine cycle, engine version A different engine cycles are compared with statistical values (average, average minus RMS, average plus RMS), 20 cycles were considered for statistical analysis.

OBRÁZEK 10: Lokální hodnoty (složky vektoru rychlosti a převrácená hodnota přebytku vzduchu) v místě zapalovací svíčky během celého pracovního cyklu motoru, verze motoru A - různé cykly motoru jsou porovnány se statistickými hodnotami (průměr, průměr mínus RMS, průměr plus RMS), 20 cyklů bylo použito pro statistickou analýzu.

total mass:

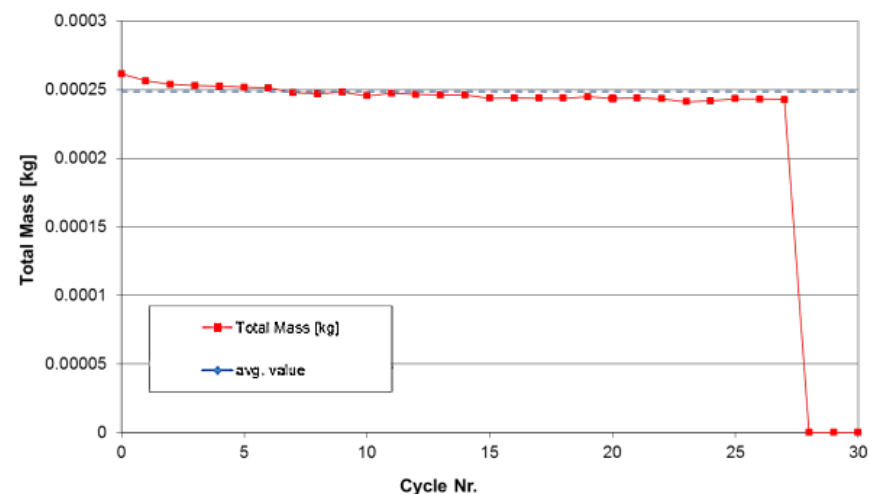

total kinetic energy:

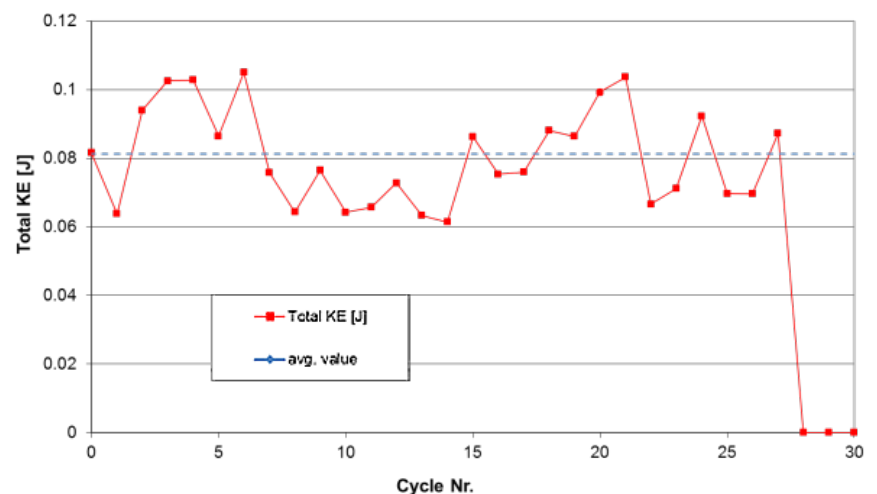


average in-cylinder air excess:

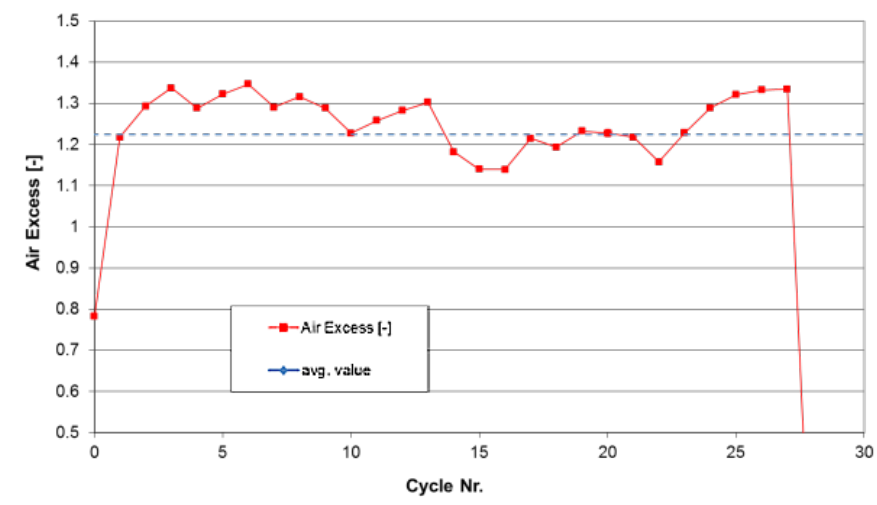

average in-cylinder EGR:

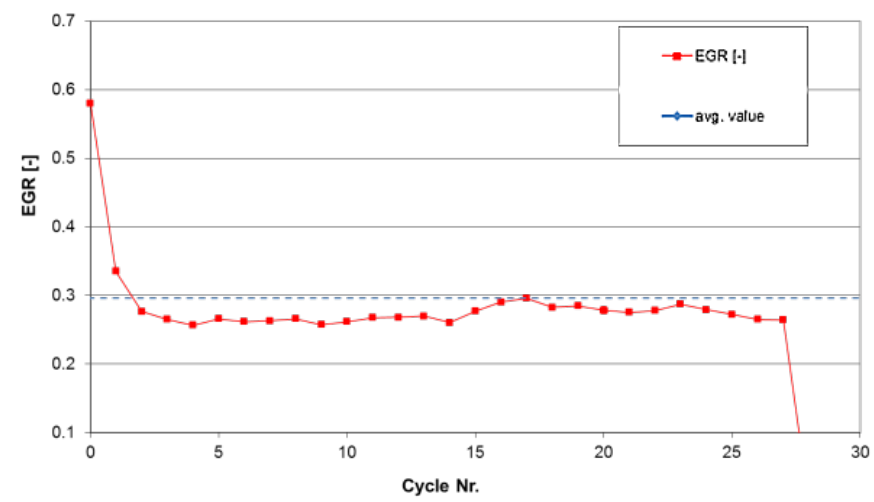

uniformity index of average in-cylinder air excess:

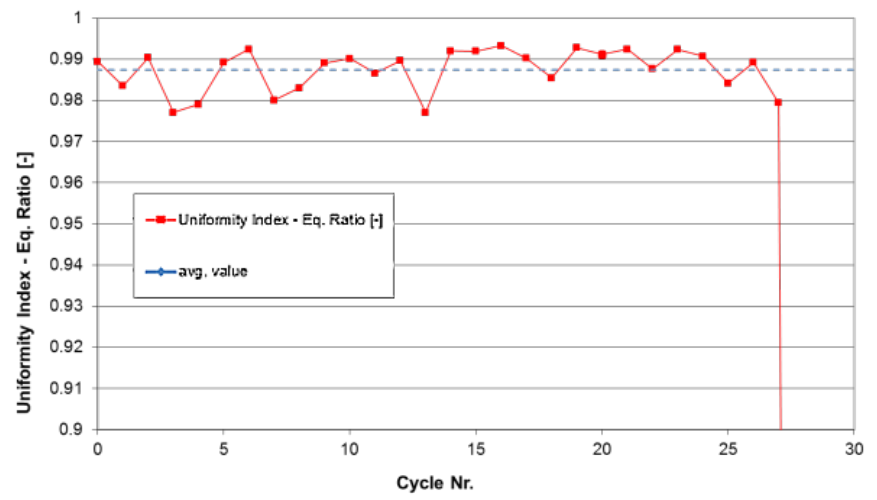

uniformity index of average in-cylinder EGR:

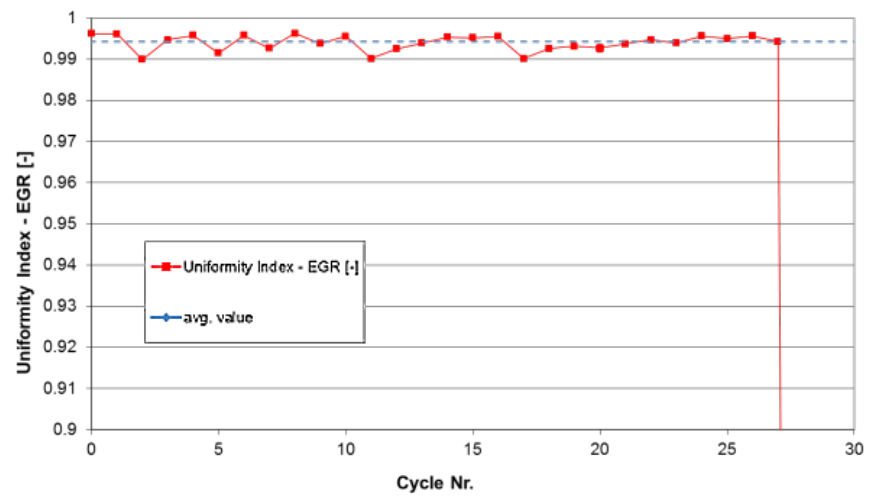

FIGURE 11: Global values (describing status in the whole combustion chamber) at time of spark ignition, engine version A - time history during the calculation of 30 consecutive engine cycles (cycles 1-3 are skipped and the curve is shifted to the left by the value of 3).

OBRÁZEK 11: Globální hodnoty (charakterizující stav v celém prostoru spalovací komory) v okamžiku zážehu, verze motoru A - časová historie 30 po sobě následujících cyklů (cykly 1 až 3 jsou vynechány a křivka je posunuta doleva o hodnotu 3).

important information at different levels of space resolution - local value, local volume/mass averaged values (e.g., gap between spark plug electrodes) and global values based on volume/mass averaging of the whole combustion chamber (e.g., average in-cylinder temperature or combustion progress in time domain). Selected examples are presented in the paper - the 3-D CFD data come from time demanding LES calculations when many consecutive cycles were calculated. As each LES engine cycle represents one realization of a particular experiment (the previous cycle directly influences the following one), it is necessary to calculate many consecutive cycles. Then an ensemble averaging modified for periodic phenomena is applied to obtain averaged values and fluctuation ones. Such approach is clearly very time consuming, however there is a lot of information available. One important issue is how many engine cycles need to be calculated to get statistically converged results.
It seems that $10-15$ cycles are needed to obtain convergence for the statistical moments of the $1^{\text {st }}$-order (e.g. averaged velocity field) while at least 40 cycles have to be calculated to get converged moments of the $2^{\text {nd }}$-order (e.g. turbulence kinetic energy). This conclusion cannot be generalized as it is based on results concerning few operating points of similar ICE type (small tumble-dominated SI ICE). However, these conclusions seem to be consistent with the well-known knowledge of other researchers dealing with application of LES to ICEs. Concerning the comparison of average LES data with RANS calculation(s), the following can be stated. The main conclusion is that the averaged velocity vector magnitude fields are relatively similar. On the other hand, the same cannot be stated for turbulence kinetic energy ones. It seems that LES predicts significantly higher values of that. When comparing both RANS models (AVL's recommended $k-\zeta-f$ and standard $k-\varepsilon)$, they are relatively similar. 
ROHR:

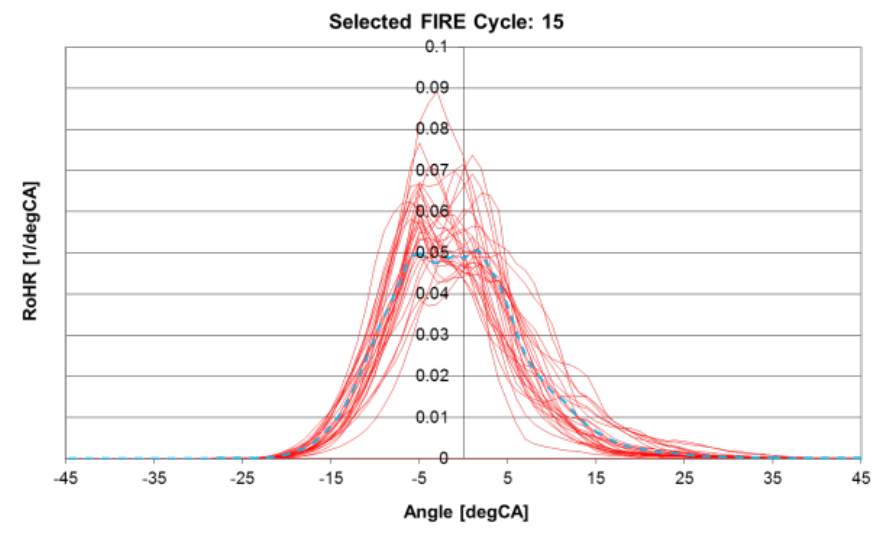

combustion duration $0-10 \%$ of MFB:

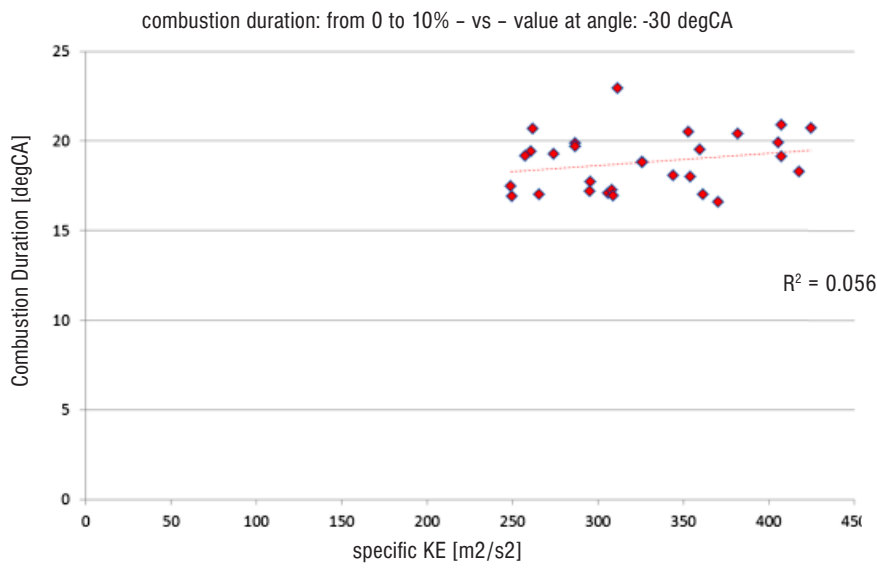

cumulative HR:

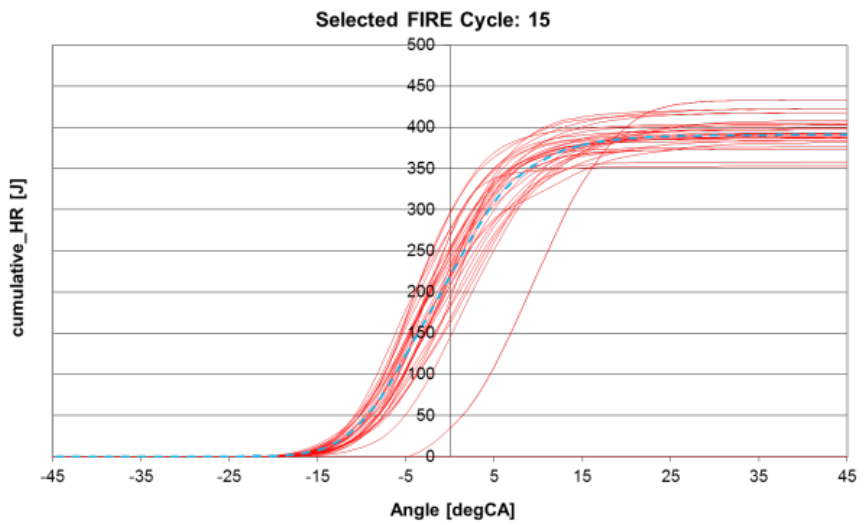

combustion duration $10-90 \%$ of MFB:

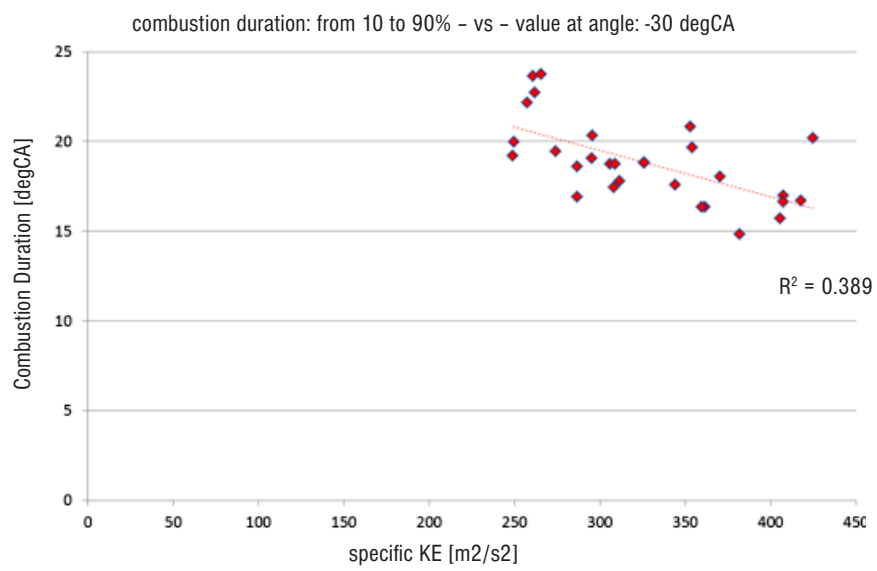

FIGURE 12: Combustion parameters (describing combustion progress in time domain), engine version $A$ - the data are based on calculation of 30 consecutive cycles (the same data set as in Figure 11).

OBRÁZEK12: Parametry spalování (popisující průběh hoření v časové oblasti), verze motoru A - data odpovídají simulaci 30 po sobě následujících cyklů (stejná sada dat jako v Obrázku 11).

The standard k- $\varepsilon$ predicts a bit higher peaks of turbulence kinetic energy and it has a better tendency to predict symmetrical results (when geometry has a plane of symmetry).

Global data (volume/mass average of the whole in-cylinder chamber) can provide important information including CCV as well. This can be used for comparison with experimental data or with predictions from system simulation SW tools (based on 0-D/1-D CFD approach). Moreover, such data can applied when performing calibration of system simulation sub-model(s). Finally, space homogeneity of any calculated property can be quantified by global values (e.g., uniformity index of average in-cylinder EGR).

Final conclusion is that statistical analysis of detailed 3-D CFD LES data, which is based on ensemble averaging, enables effective evaluation of huge amount of data. Statistics are available at different levels of space resolution (local, locally averaged, global). All these data show significant CCV, hence confirming that CCV phenomenon originates from non-linearity effects of Navier-Stoke equation set. These effects are especially important for SI ICE. It seems that LES approach (to turbulence modelling) is capable of predicting these effects relatively well.

\section{ACKNOWLEDGEMENTS}

This research has been realized using the support of The Ministry of Education, Youth and Sports program NPU I (LO), project L01311: 'Development of Vehicle Centre of Sustainable Mobility'.

All the help has been gratefully appreciated. 
LIST OF NOTATIONS AND ABBREVIATIONS

CCV Cycle-to-Cycle Variation(s)

CFD Computational Fluid Dynamics

DI Direct Injection (of Fuel)

EGR Exhaust Gas Recirculation

HR Heat Release

ICE Internal Combustion Engine

PFI Port Fuel Injection

LES Large Eddy Simulation

MFB Mass Fuel Burned

RANS Reynolds Averaged Navier-Stokes (Equation Set)

RFKE Resolved Fluctuation Kinetic Energy

ROHR Rate of Heat Release

SI Spark Ignition

\section{REFERENCES}

[1] Smagorinsky, J. (1963). General Circulation Experiments with the Primitive Equations, Mon. Weather Rev., Vol. 91(3): 99-164.

[2] Lesieur, M., Métais, O., Comte, P. (2005). Large-Eddy Simulations of Turbulence. Cambridge University Press, 40West 20 ${ }^{\text {th }}$ Street, New York, NY 10011-4211, USA. ISBN 0-521-78124-8.

[3] Vitek, O., Macek, J., Tatschl, R., Pavlovic, Z. et al. (2012). LES Simulation of Direct Injection SI-Engine In-Cylinder Flow. SAE Technical Paper 2012-01-0138, doi:10.4271/2012-01-0138.

[4] Tatschl, R., Bogensperger, M., Pavlovic, Z., Priesching, P. et al. (2013). LES Simulation of Flame Propagation in a Direct-Injection SI-Engine to Identify the Causes of Cycle-to-Cycle Combustion Variations. SAE Technical Paper 2013-01-1084, doi:10.4271/2013-01-1084.

[5] Pera, C., Angelberger, C., (2011). Large Eddy Simulation of a Motored Single-Cylinder Engine Using System
Simulation to Define Boundary Conditions: Methodology and Validation. SAE Int. J. Engines 4(1):948-963, doi: 10.4271/2011-01-0834.

[6] Wilcox, D. C. (2000). Turbulence Modeling for CFD. DCW Industries, Inc., 5354 Palm Drive, La Canada, California 91011, $2^{\text {nd }}$ edition. ISBN 0-9636051-5-1.

[7] Heywood, J. B. (1988). Internal Combustion Engine Fundamentals. McGraw-Hill series in mechanical engineering, printed in USA. McGraw-Hill. ISBN 0-07-028637-X.

[8] Hanjalic, K., Popovac, M., Hadziabdic, M. (2004). A Robust Near-Wall Elliptic-Relaxation Eddy-Viscosity Turbulence Model for CFD, International Journal of Heat and Fluid Flow, Vol. 25, pp. 1047-1051.

[9] Popovac, M., Hanjalic, K. (2007). Compound Wall Treatment for RANS Computation of Complex Turbulent Flows and Heat Transfer, In: Flow, Turbulence, and Combustion, Vol. 78, pp. 177-202.

[10]Basara, B. (2006). An Eddy Viscosity Transport Model Based on Elliptic Relaxation Approach, AIAA Journal, Vol. 44, pp. $1686-1690$.

[11]Launder, B. E. and Sharama, B. I. (1974). Application of the Energy Dissipation Model of Turbulence to the Calculation of Flow Near a Spinning Disc. Letters in Heat and Mass Transfer, Vol. 1(2):131-138.

[12] Launder, B. E. and Spalding, D. B. (1972). Mathematical Models of Turbulence. Academic Press, London.

[13]Peters, N. (2000). Turbulent Combustion. The Press Syndicate of the University of Cambridge, The Pitt Building, Trumpington Street, Cambridge. ISBN 0-521-66082-3.

[14] AVL AST (2013). FIRE Manual v2013, AVL List GmbH, Graz. 